\title{
The Yemeni Manuscript Tradition
}

Edited by

David Hollenberg

Christoph Rauch

Sabine Schmidtke

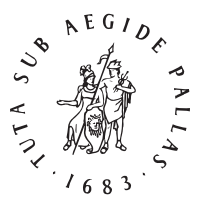

B R I L L

LEIDEN | BOSTON 


\section{Contents}

List of Figures VII

List of Contributors IX

Introduction 1

David Hollenberg, Christoph Rauch and Sabine Schmidtke

1 Was the Șan'ā’ Qur’ān Palimpsest a Work in Progress? 12 Asma Hilali

2 Yūsuf al-Bașīr's Rebuttal of Abū l-Ḥusayn al-Bașrī in a Yemeni Zaydī Manuscript of the 7 th/13th Century 28

Hassan Ansari, Wilferd Madelung and Sabine Schmidtke

3 Ms Berlin, State Library, Glaser 51: A Unique Manuscript from the Early

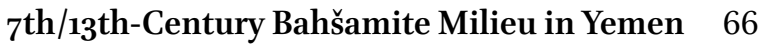

Hassan Ansari and Jan Thiele

4 The Pearl and the Ruby: Scribal Dicta and Other Metatextual Notes in Yemeni Mediaeval Manuscripts 82

Arianna D'Ottone

5 The Literary-Religious Tradition among 7 th/13th-Century Yemeni Zaydīs (II): The Case of 'Abd Allāh b. Zayd al-'Ansī (d. 667/1269) 101

Hassan Ansari and Sabine Schmidtke

6 Ms Munich, Bavarian State Library, Cod. arab. 1294: A Guide to Zaydī Kalām-Studies during the Ṭāhirid and Early Qāsimite Periods (Mid-15th to Early 18th Centuries) 155

Gregor Schwarb

7 Zaydī Scholars on the Move: A Multitext Manuscript by Yahyā Ibn Ḥumayd al-Miqrāī' (b. 9o8/1503, d. 99o/1582) and Other Contemporary Sources 203

Christoph Rauch 
8 Papiers filigranés de manuscrits de Zabīd, premier tiers du XVIII ${ }^{\mathrm{e}}$ jusqu' au milieu du $\mathrm{XX}^{\mathrm{e}}$ siècle: papiers importés et «locaux» 227 Anne Regourd

9 Șan'ā’, Jerusalem, New York: Imām Yaḥyā Ḥamīd al-Dīn (1869-1948) and Yemeni-Jewish Migration from Palestine to the United States 252 Menashe Anzi and Kerstin Hünefeld

Index of Persons and Groups 281 Index of Places and Institutions 291 Index of Books 294 Index of Manuscripts 303 


\title{
MS Munich, Bavarian State Library, Cod. arab. 1294: A Guide to Zaydī Kalām-Studies during the Tāhirid and Early Qāsimite Periods (Mid-15th to Early 18th Centuries) ${ }^{1}$
}

\author{
Gregor Schwarb
}

\section{Introduction}

This article offers a bibliographical aperçu of Zaydī kalām-studies in the period between the Banū Tāhir (middle of the 9 th/15th century) and the end of the first century of the Qāsimī dynasty (early 12th/18th century) based on Ms Munich, Bavarian State Library, Cod. arab. 1294. ${ }^{2}$ This codex contains 'Abd Allāh b. Muhammad al-Nağrî̀s as yet unedited K. Mirqāt al-anzāar which for almost three centuries constituted the backbone of Zaydī kaläm-studies. ${ }^{3}$ The body of the text is surrounded by extensive marginal notes ( hawā̌š $)$ which mostly consist of quotations from a wide variety of Zaydī and Sunnī sources dating from

1 This study was prepared within the framework of the ERC Advanced Grant Project "Rediscovering Theological Rationalism in the Medieval World of Islam". It is a revised version of a paper read at the International Workshop of The Yemeni Manuscript Digitization Initiative (YMDI), Staatsbibliothek zu Berlin, 9-10 May 2012.

2 For a brief description of the manuscript see Florian Sobieroj, Arabische Handschriften der Bayerischen Staatsbibliothek zu München unter Einschluss einiger türkischer und persischer Handschriften, Band 1 , Stuttgart: Franz Steiner, 2007, pp. 445-446 no. 234. The manuscript may be viewed at http://daten.digitale-sammlungen.de/ db/ooo3/bsbooo386oo/images/ [consulted 30/11/2013].

3 According to 'Alī al-Mūsawī Nağād, Turāt al-Zaydiyya, Qum, Ma'had Dirāsāt al-Adyān wa-lMadāhib al-Islāmiyya, 2005, p. 156, n. 2, an edition of this seminal text was announced about ten years ago by Markaz al-Turāt wa-l-Buhūt al-Yamanī in Șan'ä.'-A separate study will have to determine the exact relationship between the curricular status of K. Mirqāt al-anzāa and the status of the other major manual of ușūl al-dīn during the early Qāsimī period, K. al-Asās li-taṣhịh 'aqā’id al-Akyās by Imām al-Manșūr bi-llāh al-Qāsim b. Muhammad (d. 1029/1620), both with regard to their respective position in Zaydī curricula of $u s ̣ u$ u al-dìn and with regard to differences in doctrinal matters. K. al-Mírāğfı̌ šarh al-Minhāğ by Imām al-Hādī 'Izz al-Dīn b. al-Ḥasan (d. 900/1494-1495) was usually studied alongside K. Mirqāt al-anzāār. 


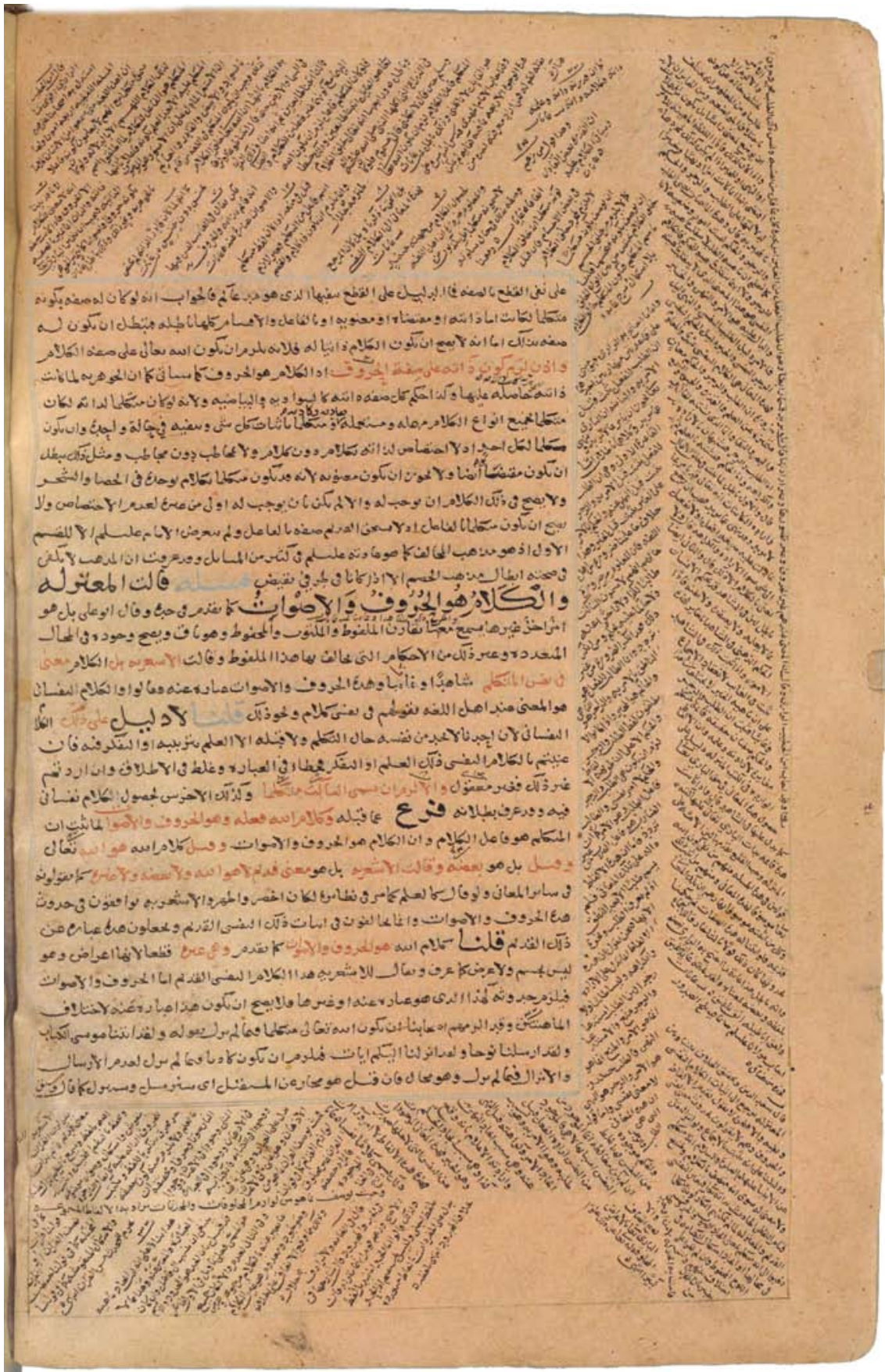

FIGURE 6.1 MS Munich, Bavarian State Library, Cod. Arab. 1294, f. $30^{v}$ 
the 4th/1oth century up to the copy date of the manuscript in 1108/1696. ${ }^{4}$ In contrast to the early reception of Bahšamì kalām among the Zaydīs in Yemen during the 6th/12th and 7 th/13th centuries, which has been the focus of several studies over the last few decades, ${ }^{5}$ the subsequent periods remain largely unexplored. ${ }^{6}$ The sources of this period, which have yet to be investigated, provide a window into an important moment in the history of Muslim kaläm. They are remarkable for their intellectual vitality, their engagement with and critical reception of multiple rival intellectual traditions and contemporaneous scholarly trends and the accordingly dense network of intertextualities they display. This article represents the first step toward filling this lacuna in the intellectual history of the Islamic world in general and of Yemen in particular.

The early 9 th/15th century - with the weakened Rasūlid state abandoning its effort to control Upper Yemen and retrenching to the south, and the Taahhirid successor state being occupied with defending coastal towns against Portuguese incursions - has at times been described as the starting point of a gradual process during which a growing number of Yemenite Zaydī scholars applied themselves to studying Sunnī literature in addition to the traditional Zaydī school texts. ${ }^{7}$ This assessment tends to discount the numerous examples

4 See below, section 3.2., for a list of the works quoted or paraphrased in the hawā̌š of MS Munich, Bavarian State Library, Cod. arab. 1294.

5 See Wilferd Madelung, Der Imam al-Qāsim ibn Ibrāhīm und die Glaubenslehre der Zaiditen, Berlin, de Gruyter, 1965; Gregor Schwarb, "Mu'tazilism in the Age of Averroes", in In the Age of Averroes: Arabic Philosophy in the Sixth/Twelfth Century, ed. P. Adamson, London, The Warburg Institute, 2011, pp. 251-282; Hassan Ansari and Sabine Schmidtke, "The literary-religious tradition among 7 th/13th century Yemenite Zaydīs: The formation of the Imām al-Mahdī liDīn Allāh Aḥmad b. al-Ḥusayn b. al-Qāsim (d. 656/1258)", Journal of Islamic Manuscripts 2 (2011), pp. 165-222; Jan Thiele, Theologie in der jemenitischen Zaydiyya: Die naturphilosophischen Überlegungen des al-Hasan ar-Rașșạș, Leiden, Brill, 2013, pp. 6-7.

6 There are a few studies in Arabic and Persian dedicated to the later period. My Handbook of Mu'tazilite Authors, Works and Manuscripts records roughly $75^{\circ}$ kaläm-treatises belonging to the Zaydī-Mu'tazili tradition in Yemen between the 7 th/13th and the $15^{\text {th }} / 21$ st centuries. For a convenient periodisation of Zaydī kalām literature see my "Mu'tazilism in a 2 oth century Zaydī Qurān commentary", Arabica 59 (2012), pp. 395-402.

7 See Nağād, Turātal-Zaydiyya, pp. 145-146 ("al-qarn al-tāsi': al-infitāh al-mad̄habì wa-l-ittiğāăh nahwa ahl al-Sunna"). This verdict is mostly due to the education, the doctrinal stance and the literary output of Muhammad b. Ibrāhīm al-Wazīr (d. 840/1436; Șārim al-Dīn Ibrāhīm b. al-Qāsim b. al-Imām al-Mu’ayyad bi-llāh Muḥammad b. al-Imām al-Manșūr bi-llāh al-Qāsim b. Muḥammad al-Šahārī (d. 1152/1739-1740), Ṭabaqāt al-Zaydiyya [al-Kubrā] (wa-yusammā Nasamātal-asḥārfițabaqāt ruwātal-ahbārr), part III (Bulūgal-murād ilā márifatal-isnād), ed. 
of Yemenite Zaydī scholars from the 6th/12th to 8th/14th centuries who devoted themselves to the study of Sunni hadit and figh literature. ${ }^{8}$

It was the first Ottoman occupation (945 [954]/1538 [1547]-1038 [1045]/1629 [1636]), and, especially, the territorial expansion of the Qāsimì state after the final eviction of the Ottomans in 1636, which brought about a massive increase

'Abd al-Salām b. 'Abbās al-Wağīh, 3 vols, Amman, Mu’assasat al-Imām Zayd b. 'Alī al-Tַaqāfiyya, 2001 [hereafter ṬZK], pp. 896-902 no. 556; for his Sunnī teachers and his rihalät fì țalab al-ilm see ȚZK., p. 899, 1367, 1458, 1514, 1586, 1595). He has been described as "the first Traditionist scholar" in the lineage of Sunnī Traditionists of highland Yemen, i.e. "scholars who argued that the Sunnì canonical hadìth collections were unconditionally authoritative in matters of religion." (see Bernard Haykel, Revival and Reform: The legacy of Muhammad al-Shawkānī, Cambridge, Cambridge University Press, 2003, pp. 10-12, 41-46 [10]). Note, however, that Ibn al-Wazīr also had a very thorough education in Zaydī-Mu'tazilì ușül. See the chapter dedicated to 'Ibn al-Wazīr' in Aḥmad Mạ̣mūd Șubḥ̄, Fī 'ilm al-kalām: Dirāsa falsafiyya li-ārā̉ al-firaq al-islāmiyya fì uṣūl al-dīn, vol. 3: al-Zaydiyya, Beirut, Dār al-Nahḍa al-'Arabiyya, 1411/1991, pp. 347-395 (378ff.) and Aḥmad b. (al-Imām al-Hādī) al-Ḥasan b. Yahyyā l-Qāsimī

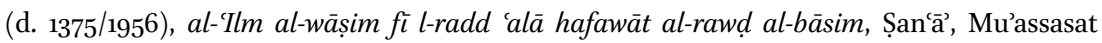
al-Imām Zayd b. 'Alī l-Taqāāiyya, 2008.

8 In ṬZK, pp. 1309-1735 (see below n. 12), the following pre-9th/15th-century Zaydī scholars (up to Ibn al-Wazīr) are mentioned to have studied with Sunnī teachers: Abū l-Ḥasan 'Ulayy b. 'Īsā b. Ḥamza Ibn Wahhās (d. 556/1161; ṬZK, pp. 105-106 no. 689), a teacher of the Qāḍī Ğa far b. Aḥmad in 555/116o, with Rukn al-Dīn Maḥmūd b. Muhammad al-Malāhịimī al-Hुwārazmī (d. 536/1141) (p. 774, 1651); 'Alī b. Ahmad al-Akwa' (ṬZK, pp. 698-703 no. 416) with 'Alī b. Muḥammad al-Ṣan‘ānī (d. after 6oo/1204) in 598/1202 (p. 1523); Humayd b. Aḥmad al-Muhallì (d. 652/1254; ṬZK, 421-424 no. 247) with Ismāōil b. Muhammad al-Ḥaḍramī (d. 676/1277-1278) (p. 1434); Sulaymān b. Muḥammad al-Šāwarī (d. 69o/1291; ṬZK, pp. 477-478 no. 279) with 'Alī b. Mas'ūd al-Kuṭbī (d. 650/1252) (p. 1536); Imām Yahyā b. Muḥammad al-Sirāḡī (d. 69o/1291; ṬZK, pp. 1252-1253 no. 791) and other Zaydī scholars with the Yemenite Šāfí̄i Aḥmad b. Mūsā b. 'Uğayl al-Ṣaḡīr (d. 69o/1291) (p. 1430); Muḥammad b. Sulaymān b. Abī l-Riğāl (d. 730/1330; ṬZK, pp. 972-981 no. 615) with the 'Irāqī Šāfíi Ahmmad b. Ibrāhīm al-Fārūṭī (d. 694/1295) in Mecca 688/1289 (p. 1345); Muhammad b. al-Muțahhar (d. 728/1328; Bт̣, p. 825ff. no. 526) with the Šāfici 'Abd Allāh al-Šağdarī (d. 719/1319) (p. 1483); Sulaymān b. Aḥmad al-Ilhānī (ṬZK, pp. 476-477 no. 278), a teacher of Yahyā b. Ḥamza, with Ahmad b. Abī l-Hुayr al-Šammāhūi (d. 729/1329) (p. 1351); Muḥammad b. 'Abd Allāh 'al-Ġazzāl' (d. ca. 740/1339; ṬZK, pp. 1001-1006 no. 631) with the 'Irāqī Šāfi'i Aḥmad b. al-Ḥasan al-Ǧārabardī (d. 746/1346) (p. 1348); Imām Yahyā b. Ḥamza (d. 749/1348-1349; ṬZK, pp. 1224-1232 no. 780) with the Meccan Šāfi īs Ibrāhīm b. Muhammad al-Ṭabarī (d. 722/1322) (p. 1315) and Muḥammad b. Muḥammad al-Ṭabarī (d. 730/1330) (p. 1641); Aḥmad b. Sulaymān al-Awzarī al-Ṣa'dì (d. 810/1407-1408; ṬZK, pp. 135-137 no. 51) with the Šāficis Ibrāhīm b. Muḥammad al-Ḥikmī (d. 793/1391) (p. 1319) and Muḥammad b. Munīr al-Zayla'ī (d. 739/1339) (p. 1650); Imām al-Mahdī Aḥmad b. Yaḥyā l-Murtaḍā (d. 840/1436; ṬzK, pp. 226-232 no. 115) and al-Hādī b. Ibrāhīm (d. 822/1419; ṬZK, pp. 1181-1185 no. 748), with the Yemenite Ḥanafī Sulaymān b. Ibrāhīm al-'Ulwī (d. 825/1422) (p. 1458). 
in the level of interaction between Zaydī scholars in Upper Yemen and Šāfici Sunnīs in Lower Yemen and exposed much larger segments of Zaydī scholars to diverse strands of Sunnī scholarship. ${ }^{9}$ From this point, some Zaydīs even adopted Sunnī positions wholesale. This gradual convergence between Zaydism and Sunnism triggered debates among Zaydī scholars over which sources were to be considered authoritative and which sources undermined the status of established Zaydī educational curricula. ${ }^{10}$ These debates had particularly profound bearings on the theological and political constituents of Zaydism and affected its legal tradition to a lesser extent.

In the realm of positive law, the doctrine of tașioib - which states that in situations of conflicting legal opinions among qualified scholars, all opinions must be considered correct - was widely accepted among Zaydī scholars and facilitated the amalgamation of multiple legal traditions and schools of law. Indeed, even prior to this point, Zaydism had a long tradition of assimilating components of Sunnī law, and several eminent Zaydī imāms had studied Ḥanafĩ law. ${ }^{11}$ Even less problematic was the adoption of works by Sunnī authors in seemingly 'innocuous' ancillary disciplines such as lexicography, grammar or logic. A good deal of information about the frequency and continuity of interaction between Zaydī and Sunnī scholars may be gleaned from the second chapter of the third part of Tabaqāt al-Zaydiyya al-kubrā dedicated to this very topic and from Sunnī texts recorded in catalogues of Zaydī manuscript collections. ${ }^{12}$

The Qāsimī imamate was established in 1598 by Imām al-Manșūr bi-llāh, al-Qāsim b. Muḥammad b. 'Alī (d. 1029/1620). See Ismāōil Qāsim al-T̄awr, Binā' al-dawla l-qāsimiyya fì l-Yaman fì 'ahd al-Mu'ayyad Muhammad b. al-Qāsim, 990/1582-1054/1644, ma'a tahqīq mahțūtat al-Ǧawhara l-munira fi ğumal min 'uyūn al-sīra li-l-Muțahhar b. Muhammad al-Ğurmūzī, Șan'ā’, Mu'assasat al-Imām Zayd b. 'Alī l-T̃aqāfiyya, 2008; Robert W. Stookey, Yemen: The Politics of the Yemen Arab Republic, Boulder, Westview, 1978, pp. 127-166. G. Rex Smith, Studies in the Medieval History of the Yemen and South Arabia, Aldershot, Variorum, 1997, articles nos. XV-XVI. idem, "Al-Yaman", $E I^{2}$, vol. 11, p. 273.

Haykel, Revival and Reform, pp. 194-197. The debates about character and identity of the Zaydi madhab and questions of legal authority in the early 12th/18th century are part of this process; see Bernard Haykel and Aron Zysow, "What makes a Madhab a Madhab:Zaydī debates on the structure of legal authority", Arabica 59 (2012), pp. 332-371. See Schwarb, "Mu'tazilism in the Age of Averroes", p. 256 with n. 26.

12 ȚZK, vol. 3, pp. 1309-1735: fi dikr man rawā 'anhu a'immatunā aw š̌̃atuhum 'an ahad min 'ulamā' al-fuqahä' min ahl al-sunna al-rāği ìn ilā l-fuqahā' al-arba'a wa-mā ițtala'nā 'alayhi min asānídihim. Another seminal source abounding with information about the relation between Zaydī and Šāfi'î-Aš‘arī scholars in the early Qāsimī State is Muṭahhar b. Muḥammad al-Ğarmūzīs (d. 1077/1666) Tuhfat al-asmā̄' wa-l-abṣār bi-mā fì l-sīra alMutawakkiliyya min ġarāib al-ahbār (ed. 'Ammān: IZbACF 2002) which contains the sïra of Imām al-Mutawakkil Ismā'īl b. al-Qāsim (d. 1087/1676). 
In the domain of ușūl al-dīn, however, tașwīb was applicable neither to Zaydī-Mu'tazilī nor Sunnī-Ašcarī doctrine. ${ }^{13}$ Hence, attempts to accommodate Zaydī ușūl al-dīn to Sunnī Ašarism presented Zaydī scholars with a far more serious challenge. It potentially threatened the core of Zaydī identity, which is based on theological and political convictions rather than legal authority or a homogeneous body of law. Assimilating Zaydī uṣūl al-dìn and 'ilm al-kalām to Ašcarī theological doctrines would therefore be tantamount to relinquishing Zaydī identity.

The reception of an Avicennised Ašarite kalām was not new to Zaydī scholars of the Țāhirid and Qāsimī periods. From the early 7 th $/ 13$ th century onwards, Yemenite Zaydī mutakallimūn started to grapple with the massive impact of Faḩral-Dīn al-Rāzī’s (d. 606/1210) works. The writings of Yahyā b. Hamza (d. 749/ 1348-1349), 'Imād al-Dīn al-Qurašī (d. 780/1378-1379), Aḥmad b. Yahyaa lMurtaḍā (d. 840/1436-1437) and other eminent Zaydī scholars abound with references to Rāzī's œuvre and critical discussions of his theologico-philosophical positions.

What was new was the scale and the intensity of Zaydī exposure to Sunnī kalām literature. It called for new resources to steer Zaydī mutakallimūn safely between the Scylla and Charybdis of Ašarī doctrines. Zaydī scholars learned to read the major summae and manuals of post-Avicennian Ašarism "against the grain" and to play one Ašarī scholar against another; selected passages in the works of 'Aḍud al-Dīn al-İ̌̆īi, Sacd al-Dīn al-Taftāzānī, al-Šarīf al-Ğurğānī and other authors of influential Sunnī kalām compendia were adduced whenever their positions were deemed to be reconcilable with Zaydī theological doctrine or useful to clarify its exposition. 'Abd Allāh b. Muḥammad al-Nağrī was a key figure and model for his successful negotiation between Zaydī uṣūl (al-dìn/alfiqh) and non-Mu'tazilī Sunnī kalām.

\section{'Abd Allāh b. Muḥammad al-Nağrī: Life and Work}

According to most sources, Faḩr al-Dīn 'Abd Allāh b. Muhammad b. Abī l-Qāsim al-Nağrī was born in 825/1422 in Ḥūt, the well-known urban settlement situated at an important crossroads halfway between Șan`ā’ and Șa'da. Other sources

13 This does not imply that ușül al-din is beyond the realm of iğtihäd. Quite the contrary, according to Imām al-Mahdī Aḥmad b. Yahyyā l-Murtaḍā 'ilm uṣūl al-dīn is "al-hâamis min al-'ulūm al-mu'tabara fì l-iğtihād [...] wa-huwa ahamm al-mu'tabarāt 'indanā" (MS London, British Library, Or. 3937, f. 8b-9a). 
claim that he was born in al-Qābil, a small village in Wādī Ḍahr, approximately 20 kilometers south of Șacda where he was buried in 877/1472-1473. ${ }^{14}$ The various biographical accounts usually state that he began his education in naḥw, fiqh and the ușülān (scil. ușūl al-dīn and ușül al-figh) with his father ${ }^{15}$ and his elder brother 'Alī ${ }^{16}$ in Hūt where he spent his youth. Next, they mention his hağğ to Mecca in Dū l-Hiğğa 848/March 1445 emphasizing the fact that he did not return to Yemen. Instead, he boarded a ship and embarked on a rihla fi talab al-ilm to Mamlūk Cairo where he arrived three months later, in Rabí` i 849/June 1445. On account of this rihla, he is commonly referred to as al-faqīh al-rahḥ̂ăl al-mutakallim allad̄ì raḥala ilā l-bilād wa-laqiya l-šuyūhn. ${ }^{17}$

14 The main sources for his life are: Yahyāa b. al-Ḥusayn b. al-Imām al-Manșū bi-llāh al-Qāsim (d. 1100/1688), K. al-Mustațāb fi tarāğim 'ulamā’ al-Zaydiyya al-atyāb (= K. al-Tabaqāt fì dikr (fadll) al-ulamā’ wa-ilmihim = Țabaqāt al-Zaydiyya al-Ṣugrā) [hereafter ȚZș], MS (microfilmed) Ḍahyān, Maktabat Muḥammad b. 'Abd al-'Aẓ̇im al-Hādī; see 'Abd al-Salām b. 'Abbās al-Waḡīh, Mașādir al-turāt fí l-maktabāt al-ḩāșșa fì l-Yaman, Amman, Mu’assasat al-Imām Zayd b. 'Alī al-Ṭaqāfiyya, 2002 [hereafter мTMHुY], vol. 1, p. 514 no. 408; vol. 2, pp. 67-68; Šihāb al-Dīn Aḥmad b. Șāliḥ Ibn Abī l-Riğāl (d. 1092/1681), Mațlac albudūrwa-mağma'al-buhūur (fìtarāğim riğālal-Zaydiyya) [hereafter м в], ed. 'Abd al-Raqīb Muṭahhar Muḥammad Ḥağar, 4 vols, Șan'ā', Markaz Ahl al-Bayt li-l-Dirāsāt al-Islāmiyya, 1425/2004, vol. 3, pp. 129-133 no. 805; ȚZ, pp. 635-639 no. 383 (with further literature on p. 635, n. 5); Muḥammad b. 'Alī b. Muḥammad al-Šawkānī (d. 1250/1835), al-Badr al-Ṭālic bi-mahāsin man ba'd al-qarn al-sābic, ed. Muḥammad Ḥasan Ḥallāq, Damascus/Beirut, Dār Ibn Kațīr, 1427/2006 [hereafter BṬ], vol. 1, pp. 436-438 no. 272; 'Abd Allāh Muhammad al-Ḥibšī, Mașādir al-fikr al-islāmī fì l-Yaman, Abu Dhabi, al-Mağma' al-Tַaqāfī, 2004² [hereafter M FY], pp. 29, 137f., 226, 385, 425, 586; 'Abd al-Salām b. 'Abbās al-Wağīh, A'tām al-mu'allifin al-Zaydiyya, 'Ammān, Mu'assasat al-Imām Zayd b. 'Alī al-Taqafiyya (IZbACF), 1420/1999 [hereafter AMZ], pp. 616-618 no. 635; Carl Brockelmann, Geschichte der arabischen Litteratur. Supplementbände 1-3, Leiden, Brill, 1937-1942 [hereafter GALS], vol. 2, p. 247 no. 8c. 'Umar Riḍā Kaḥhāāa, Mư̆ğam al-mu’allifin: tarāğim muṣannifí al-kutub al'arabiyya, Damascus, Mațba'at al-Taraqqī, 1957-1961 [hereafter MM], vol. 6, p. 137; Qāsim

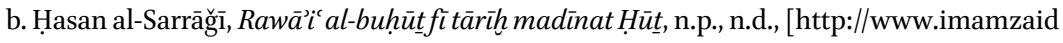
.com/books/hoth.chm (accessed 30/11/2013)], no. 167; Schwarb, "Mu'tazilism in a 2oth Century Zaydī Qư’ān commentary", p. 400.

15 For his father, Muḥammad b. Abī l-Qāsim al-Nağrī (d. 852/1448), see ṬZK, no. 666; Rawā̄ic al-buḥūt fì tārīh madīnat Ḥūt, no. 314 .

16 For his brother, 'Alī b. Muhammad al-Nağrī (d. 844/1441), who was himself a legal scholar of

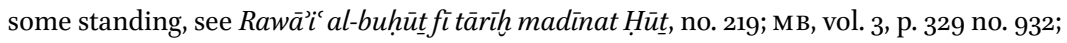
ȚZK, pp. 789-79o no. 490; AMZ, pp. 716-717 no. 770. He was apparently considerably older than 'Abd Allāh. He studied with Imām al-Mahdī from whom he received an iğāza in $822 / 1419$.

MB, vol. 3, p. 129; ṬZK, p. 638 . 
Some sources stress that he was hiding his Zaydī identity during his stay in Cairo and purported to be a Ḥanafì scholar (wa-tasattara muddata baqāihi bi-Mișr, fa-lamyantasib ilā l-Zaydiyya wa-ntasaba ilā l-Hanafiyya). ${ }^{18}$ This in turn would explain the oddity that al-Nağrī figures in the biographical dictionaries of Ibrāhīm b. 'Umar al-Biqā̄ì (d. 885/1480) ${ }^{19}$ and Šams al-Dīn Muḥammad b. 'Abd al-Raḥmān al-Sahāwī (d. 902/1497) ${ }^{20}$ (wa-li-hādā tarğamahu al-Biqā̄i $w a-l-S a h \bar{a} w \bar{\imath}) \cdot{ }^{21}$

According to all biographical accounts, al-Nağrī studied a wide range of disciplines during his stay in Cairo. Al-Aḍud 'Abd al-Raḥmān b. Yahyā alȘayrāmī (d. 880/1474) ${ }^{22}$ and Amīn al-Dīn Yaḥyā b. Muḥammad al-Aq̣̦arā̄ī (d. 880/1475) are mentioned as his teachers in Hanafì law. Consequently, both were included in the Tabaqāt al-Zaydiyya al-kubrā in the afore-mentioned section on Sunnī teachers of Zaydī scholars. ${ }^{23}$ The same holds for Ahmad b. Muhammad al-Šumunnī (d. 872/1468), an Alexandria born Ḥanafĩ scholar from a Mālikī family of Mag̉ribī origin with whom al-Nağrī studied ilm alma'āni wa-l-bayān. ${ }^{24}$ Besides, he studied grammar (naḥw wa-șarf) with Abū Ḥafș 'Umar Ibn Qadīd al-Qalamțâ̄ī (d. 856/145225 and Abū l-Qāsim al-Nuwayrī (d. 857/1453), manțiq (i.e. al-Kātibī's Šamsiyya and commentaries) with Abū Bakr b. Muḥammad al-Taqī al-Ḥiṣnī (d. 881/1476), ${ }^{26}$ 'ilm al-waqt with 'Izz al-Dīn 'Abd al-'Azīz b. Muḥammad al-Wafāī al-Mìqātī (d. 876/1471), and handasa with Abū l-Faḍl al-Mag̉ribī (d. 864/1460). ${ }^{27}$ Al-Sahāwī highlights al-Nağrî’s study of al-Šarîf al-Ğurğāni’s (d. 816/1413) ${ }^{28}$ Šarh al-Mawāqif with the

18 BṬ, vol. 1, p. 437; Rawā̉i al-buḥūt (above n. 14).

19 Iẓhàr al-'aṣr li-asrār ahl al-'aṣr (= Tārīh al-Biqā̄ī), written as a dayl to Ibn Hağar al'Asqalānī's (d. 852/1449) Inbā' al-Ġumr bi-abnä’ al-'umr, covering the years 853/1449879/1474-1475, under the year 853/1449. The edition in three volumes by Muhammad Sālim b. Šadīd al-'Awfì (Cairo/Giza, 1412/1992-1414/1993) only comprises the years Muharram 855/Feb 1451-Dū l-Ḥiğğa 865/Sep 1461. Walid Saleh has kindly checked the extant musawwada-manuscript of the first part of the Izhār, but was unable to find the entry on al-Nağrī.

20 al-Ḍaw’al-lāmi li-ahli l-qarni l-tāsi', ed. Cairo, Maktabat al-Qudsī, 1354/1935, vol. 5, p. 62.

21 BṬ, p. 437; M B, vol. 3, pp. 130-131.

22 Misspelled as 'al-Ṣayrāfì' in ṬZK, p. 636.

23 ṬZK, pp. 1708-1709 no. 898 (al-Șayrāmī). ṬZK, p. 1705 no. 894 (al-Aqșarā̄ì). See above n. 12.

24 T.ZK, pp. 1706-1708 no. 897.

25 ŢZK, p. 1701 no. 893.

26 Sahāwī, al-Daw' al-lāmic, vol. 11, pp. 76-77 no. 212.

27 Sahāwī, al-Daw' al-lāmi, vol. 9, pp. 180-188 no. 466.

28 On him see now Josef van Ess, Die Träume der Schulweisheit: Leben und Werk des 'Al̄ $b$. Muḥammad al-Ǧurğānī (gest. 816/1413), Wiesbaden, Harrassowitz, 2013. 70 years before al- 
above-mentioned al-Taqī al-Hișñ̄i ${ }^{29}$ and Ǧābir b. Aflaḥ’s K. al-Tabșira with alĞağmīnī. ${ }^{30}$

For our purposes, al-Nağrīs studies with al-Taqī al-Ḥișnī deserve particular attention. According to al-Sahāāīi, ${ }^{31}$ al-Taqī al-Hiṣnī spent five years in Herat studying at the newly built Timurid madrasa inaugurated by Šāh-Ruh in 813/1410-1411. ${ }^{32}$ With Šams al-Dīn Muḥammad b. Mūsā al-Ğāğarmī (d. 864/ 1459), a student of Ğalāl al-Dīn Yūsuf b. al-Qāsim al-Hallāğ (d. 823/1420) (a student of al-Šarīf al-Ğurğānī), he studied the works of 'Aḍud al-Dīn al-Iğīì alŠarīf al-Ǧurğānī's Šarh al-Mawāqif and a commentary on al-Bayḍāwī's Ṭawālic al-anwār, most probably Maḥmūd b. 'Abd al-Raḥmān al-Iṣfahānī's (d. 749/1348) Mațāli' al-anzār 'alā Ṭawāli' al-anwār. ${ }^{33} \operatorname{In} 845 / 1441-1442$, only four years before al-Nağrì's arrival in Cairo, al-Taqī al-Hịṣnī returned to Egypt and took up a teaching position at al-Azhar. ${ }^{34}$

It is unclear how long al-Nağrī stayed in Cairo. Judging from what al-Biqā̄i writes under the year 853 AH, al-Nağrī was still in Cairo at the beginning of that year (February 1449). He probably returned to Yemen later that year, after more than four years of study in Cairo. Mațlac al-budūr and Tabaqāt al-Zaydiyya al-șugrāalal-kubrā all mention that he was the first to introduce certain books into Yemen, and specifically refer to Ğamāl al-Dīn 'Abd Allāh

Nağrī, al-Ǧurǧānī had himself spent four years studying in Cairo between 776/1374 and 779/1377 (see ibid., pp. 22-25). Šarh al-Mawāqif was completed in 807/1405 in Samarqand.

29 The names of al-Nağrî̀s teachers got mixed up in the sources: according to al-Sahāwī, al-Dạw' al-lāmi', al-Nağrī studied Šarh al-Mawāqif with al-Ğag̉mīnī who was, however, an astronomer. According to ṬZK he studied the book with "al-Ḥuqayni” which should be read as "al-Ḥișn̄̄" (see below).

30 He likely is a descendant of the famous 14th century astronomer Mahmūd b. Muhammad al-Ğag̉mīnī.

31 See above n. 26.

32 See Maria Eva Subtelny and Anas B. Khalidov, "The Curriculum of Islamic Higher Learning in Timurid Iran in the Light of the Sunni Revival under Shāh-Rukh", Journal of the American Oriental Society 115 (1995), pp. 210-236 (212-214).

33 Al-Ğăğarmī and al-Taqī al-Hișnī also appear in isnāds of the Šāficī-Ašcarī Aḥmad b. Muhammad Ibn Ḥağar al-Haytamī (d. 974/1567; ṬZK, pp. 1370-1428 no. 845) who is said to have transmitted the works of al-Taftāzānī and al-Šarīf al-Ğurğānī to some Zaydī scholars (see ṬZK, p. 1372, 1412-1413, where al-Taqī al-Ḥișnī is referred to as "Šayh al-Šāfíiyya al-Taqī b. Šādī”). In the isnād relating to the works of al-Šarîf al-Ǧurğānī his name is misspelled as

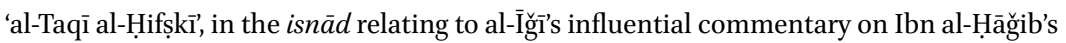
Muhtașar Muntahā al-su’l as 'al-Taqī b. Sādī al-Ḥuqayfakī' (ibid.).

On the way back he was robbed of all the books he had acquired during his riḥla. 
b. Yūsuf Ibn Hišām's (d. 761/136o) Muginī l-labīb ('an kutub al-a'ārīb) (huwa awwal man qaddama bi-Muginī l-labīb min Mișr ilā l-Yaman, tumma wașala bihi al-Rimī al-Šăfici ba'dahu ila Șan'ẩ). ${ }^{35}$ It is likely that he was also the first to introduce al-Šarīf al-Ǧurğānīs Šarḥ al-Mawāqif, Sacd al-Dīn al-Taftāzānī's (d. 792/1390) Šarh al-Aqā’id al-nasafiyya and similar works to Upper Yemen. ${ }^{36}$ Both are repeatedly quoted in K. Mirqāt al-anz $\bar{a} r$ and later became important reference texts in Zaydī theological works of the Qāsimī period. According to some reports, al-Nağrī wrote his Šarh Muqaddimat al-Baḥr [al-zahh̆ār] (= K. Mirqāt al-anzāar) on his way back from Cairo to Yemen (șannaftuhu fì safarì qāfil ${ }^{a n} \min$ Mișr $) .{ }^{37}$

After his return from Egypt, al-Nağrī attached himself to Imām al-Mutawakkil al-Muțahhar b. Muḥammad b. Sulaymān (d. 879/1474), an eminent student of Imām al-Mahdīi ${ }^{38}$ Al-Mutawakkil's intellectual profile and the range of $u s \underline{u} l$-works he studied and taught share many commonalities with al-Nağrì's formation in the $u s \bar{u} l$-sciences. ${ }^{39}$ During this period, al-Nağrī forged a close collaboration with 'Alī b. Muḥammad al-Bukurī (d. 882/1478).40 Together with Šams al-Dīn Aḥmad b. Muḥammad al-Huālidī (d. 880/1475; ṬZK, p. 203 f. no. 96), they formed the scholarly core group in the entourage of al-Mutawakkil. ${ }^{41} \mathrm{Al}-\mathrm{Nağrī}$ and al-Bukurī co-authored a commentary on the introduction

35 ȚZK, p. 639. For Mügnīl-labïb see Carl Brockelmann, Geschichte der arabischen Litteratur 12. Zweite den Supplementbänden angepasste Auflage, Leiden, Brill, 1943-1949 [hereafter GAL], vol. 2, p. 23; GALS, vol. 2, p. 17 .

$3^{6}$ I am not aware of any reference to these works in Zaydī literature prior to al-Nağrī’s Mirqāt al-anzār.

37 ȚZK, p. 637.

38 On al-Mutawakkil see ṬZK, pp. 1130-1134 no. 712; вṬ, pp. 865-866 no. 556. Al-Mutawakkil's imāmate was rivalled by al-Nașīr b. Muḥammad. In the 86os the Țāhirid took full advantage of this rivalry and temporarily even gained control over Șanāa as they did later on from 910/1505 till 923/1517.

39 His study of Zaydī literature was based on the works of Imām al-Mahdī Aḥmad b. Yaḥyā l-Murtaḍā. Among the Sunnī works which he studied figure three commentaries on al-Qazwīnī's Talhūṣ al-Miftāh, including al-Taftāzānī's Muțawwal, al-Ī̌̄ìs commentary on Ibn al-Hāăğib's Muhtașar Muntahā al-su'l and several supercommentaries, al-Subkī's Raf ${ }^{c}$ al-Ḥāğib, al-Ișbahānī's Bayān al-Muhtașar, and so forth (ṬZK, pp. 1131-1132). Ibn al-Ḥāğib's Muhtașar and its commentaries became a mainstay of Zaydì ușül al-figh in the 9th/15th century in addition to the earlier Zaydī-Mu'tazilī tradition.

ȚZș, vol. 2, p. 73; MB, vol. 3, pp. 330-334 no. 935; вṬ, pp. 531-532 no. 333; AMZ, pp. 709-710 no. 76o; MM, vol. 7, pp. 180-181; Schwarb, Handbook, no. 441. Wa-kānā ma' al-Huâlidī quṭ̂b dawlatihi (MB, vol. 3, p. 331). 
of al-Bayān al-šăfi $\iota^{42}$ by Yahyā b. Aḥmad Ibn Muẓaffar (d. 875/1470), another notable student of Imām al-Mahdī ${ }^{43}$ and a widely read treatise on the imāmate. $^{44}$

Apart from his uṣul-works, al-Nağrī also wrote on grammar (Šarh Muqaddimat al-Tashïl li-bn Mãlik) ${ }^{45}$ and logic (Hidāyat al-mubtadi' wa-bidāyat almuhtadī). ${ }^{46}$ First and foremost, however, he is known for his legal treatises which have attracted much attention beyond the narrow confines of Zaydi scholarship: Šăfí al-'́alïl fi šarh al-hamsimiati āya min al-tanzïli7 and the unfinished $^{48}$ K. Míyār a äwār al-afhām fíl-kašf 'an munāsabāt al-ahkāmm which both betray distinctive marks of his studies in Cairo. ${ }^{49}$

42 MFY, p. 218, 227, gives the title of Šarḥ Muqaddimat al-Bayān al-šăfi as al-Bustān al-ǧāmic li-l-fawākih al-ḥisān.

43 мв, vol. 4, pp. 486-487 no. 1325; ṬZ, pp. 1205-1206 no. 764; AMZ, pp. 1092-1093 no. 1168; GALS, vol. 2, p. 244 no. 5. Muhammad b. Ṣalāḥ al-Falakī al-Farāiḍī (d. 1073/1662-1663) is quoted as saying that al-Bukurī excelled al-Nağrī in the domain of ușül al-dīn, while al-Nağrī excelled al-Bukurī in uṣūl al-fiqh: Wa-șannafā ğamīan šarhan li-Muqaddimat al-Bayān, fa-l-Bukurī šaraḥa uṣūl al-dīn wa-l-Nağrī šaraḥa ușūl al-figh (мB, vol. 3, p. 330; ṬZK, p. 638). Al-Bayān al-šăfi is a multi-volume legal work based on Qāḍī Muhammad b. Ḥamza b. Muẓaffar's (d. 796/1394) al-Burhān al-kāfı with an ușūl-introduction. ȚZK, p. 638 and м B, vol. 3, p. 130, erroneously attribute Šarh Muqaddimat al-Bahr al-zahhāār to al-Nağrī and al-Bukurī due to a confusion with Šarh Muqaddimat al-Bayān.

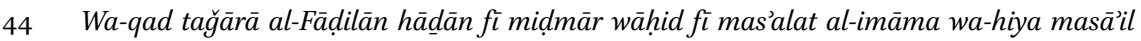
dā’ira bayna l-nās (M B, vol. 3, pp. 330-331). See Muḥammad Yahyā Sālim 'Azzān, "Qirāaa fi nazariyyat al-imāma inda l-Zaydiyya", al-Masār 9 (1423/2002), pp. 1-49 (http://yemenhrc .info/Files/ALMasarArticles/77.pdf) [consulted 30/11/2013]; idem (ed.), Hiwwār fï l-imāma, Șancā', Markaz al-Turāt wa-l-Buhūt al-Yamanī, 1424/2003 (with texts by al-Nağrī, al-Bukurī, 'Izz al-Dīn b. al-Ḥasan, and Șārim al-Dīn Ibrāhīm al-Wazīr). 'Azzān was imprisoned during the Sa'da wars after 2004 because of the political sensitivity of his research.

Ǧamāl al-Dīn Muḥammad b. 'Abd Allāh Ibn Mālik (d. 672/1274), Tashīl al-Fawāìdwa-takmül al-maqāșid. MFY, p. 385 .

46 MFY, p. 586.

47 Ed. (first part only) Aḥmad b. 'Alī b. Aḥmad al-Šāmī, Șanāà/Beirut, Maktabat al-Ǧīl alĞadīd/Mu'assasat al-Kutub al-Taqāfiyya, 1986. This edition has been severely criticised as "pro-Sunnī" and "anti-Zaydī". The remaining parts of the book have been edited in various M.A. and doctoral theses (see http://www.yemen-nic.info/contents/studies/detail .php?ID=23703 and http://www.quran-c.com/display/Disptitle.aspx?UID=5912\&CID=177 [consulted 30/11/2013]). MFY, p. 29.

48 According to a note at the end of Ms Munich, Bavarian State Library, Cod. arab. 1282, f. $75 \mathrm{~b}$,

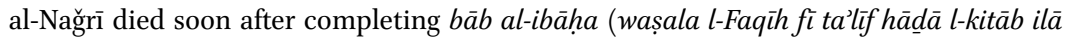

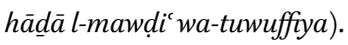

K. Mi'yār a ġwār al-afhām (a manuscript of which may be viewed at http://makhtota.ksu 
Al-Nağrī's principal uṣūl-work, written in 853/1449-1450, is known under various titles:

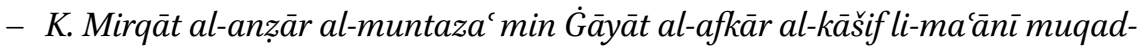
dimat(/dībāğat) al-Baḥr al-zahhūàr ['alā tawhìdāt al-Wāḥid al-Qahhār]

- Šarh Muqaddimat al-Baḥr [al-zahhōar]

- Šarh al-Qalāid fi taṣḥ̄h al-'aqã̄id

- Šarḥ al-Qalā'id al-muntaza'min al-Durar al-farā’id fì taṣḥịh al-'aqā’id

- Šarḥal-Nağrĭ ${ }^{50}$

- Šarḥ al-Nağrí 'alā Muqaddimat al-Baḥr / Šarḥ al-Nağrī 'alā l-Qalāid

Mirqāt al-anzāar is a commentary on the second introductory section (K. al-

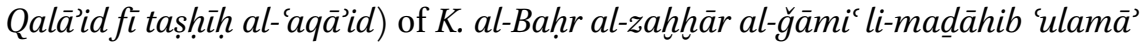
al-amṣār, Aḥmad b. Yaḥyā l-Murtaḍā's (d. 840/1436-1437) comprehensive digest of Zaydī-Hādawī law preceded by six introductory sections (dībāğa/muqaddima). ${ }^{51}$ It is not, however, excerpted (muntaza) from the second book (K.

.edu.sa/makhtota/3138/1 [consulted 30/11/2013]) was the subject of two M.A. theses submitted at Egyptian universities: 'Abd Allāh 'Umar Aḥmad al-Ǧurūw, K. Mi'yār a àwār alafhām fì l-kašf'an munāsabāt al-aḥkām, ta’līf 'Abd Allāh b. Muḥammad al-Nağrī al-Yamānī al-mutawaffi 877h: tahqīq wa-dirāsa, Cairo University, Kulliyyat Dār al-'Ulūm, Qism alŠarīa al-Islāmiyya, 1992 (http://www.islamfeqh.com/Kshaf/List/ViewRasaelDetails.aspx ?RasaelID=992) [consulted 30/11/2013]; 'Abd al-Ḥafiz 'Abd Allāh Muḥammad al-Rumayma, Maqāṣid al-šarīa ind al-Zaydiyya:Dirāsa tațbīqiyya fífiqh al-Allāma 'Abd Allāh b. Muḥammad al-Nağrī al-Yamānī, University of Alexandria, 2010 (http://marebpress.net/news _details.php?sid=24208\&lng=arabic) [consulted 30/11/2013]. According to al-Rumayma alNağri’s Mi'yār was influenced by two of the most prominent precursors of the maqāṣid al-šarīa and mașālih al-qawā'id tradition, namely 'Izz al-Dīn ('Abd al-'Azīz) b. 'Abd alSalām (d. 66o/1263) and the latter's student Šihāb al-Dīn Abū l-'Abbās Aḥmad b. Idrīs al-Qarāiì (d. 684/1285). MFY, p. 226.

50 "Šarh al-Nağrī" is an ambiguous reference, because it is also used to designate 'Alī b. Muḥammad al-Nağrì's commentary on al-Mahdī’s K. al-Azhār (Šarh al-Nağrī 'alā l-Azhārr= K. al-Anwārwa-ğalā’al-athmār al-mufattiḥ li-kamā'im al-Azhār al-muntaza'min al-Ghayth al-midrār). The fact that Ṣalāḥ b. 'Alī al-Mị̣wāḥi (d. after 1007/1598-1599; MB, vol. 2, p. 491) also wrote a commentary on the muqaddima of $K$. al-Azhār with the title "Mirqāt al-anzār fı̌ šarh muqaddimat al-Azhār" has further contributed to the confusion in the catalogues.

51 For al-Mahdī see ṬZK, pp. 226-233 no. 115; вт̣, pp. 155-159 no. 77; AMZ, pp. 206-213 no. 199; 
al-Durar al-farāidd) of $\dot{G} \bar{a} y \bar{a} t$ al-afkār as some title variants would seem to suggest. Because of its intermediary size between the very concise K. al-Qaläid and the lengthy K. al-Durar, al-Nağri’s Mirqāt al-anzār served both as an explanatory elucidation of the first and as an access gate to the second.

The position of $K$. al-Qalä’id within al-Bahr al-zahhāar and of $K$. al-Durar within $\dot{G} \bar{a} y \bar{a} t$ al-afkār can be gleaned from the following synoptic table. $\dot{G} \bar{a} y \bar{a} t$ al-afkār consists of an introduction and nine disciplinary sections (funūn)..52 Funūn 1-6 are commentaries on the six parts of the Dībäğa of K. al-Bahr alzahhār (ed. Tāmir, vol. 1), while funūn 7-9 are commentaries on its principal legal part (K. al-Ahkām al-mutadammin li-figh äimmat al-Islām) and two of its appendices (ed. Tāmir, vols 2-6). In the general introduction to $\dot{G} \bar{a} y \bar{a} t$ al-afkār, Ibn al-Murtaḍā describes the encyclopaedic Ġāyāt-project as Kitāb

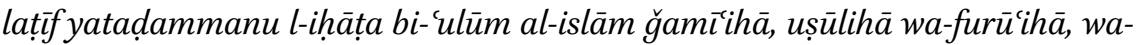
stiqșă $\bar{a}^{\prime}$ masā̉il al-hilāfbayna firaq al-umma wa-qawā'idihā allatī tațbutu 'alayhā furū'uhā. ${ }^{53}$

GALS, vol. 2, pp. 244-246 no. 6; MFY, pp. 583-594; MTY, pp. 192-217. K. al-Bahr al-zahhāar has been reprinted several times (Baghdād, Maktabat al-Mutannā, 1947-1949; Beirut, Mu'assasat al-Risāla, 1975). In the following I will quote according to ed. M.M. Tāmir, 6 vols, Beirut, Dār al-Kutub al-Ilmiyya, 1422/2001.-Other glosses and commentaries on K. Qalāìd are mostly dependent on K. Mirqāat al-anzāār: 1) Ğamāl al-Dīn 'Alī b. Dāwūd b. Aḥmad al-Ḥayyī (d. after 920/1514), Šarh al-Qalä̀id (м B, vol. 3, pp. 238-239; Schwarb, Handbook, no. 444/1); 2) al-Ḥasan b. Yahyā Saylān al-Sufyānī (d. 1110/1698-1699), Ḥāšiya 'alā l-Qalāidf fìtașhịh al-'aqā̉id (ṬZK, pp. 350-351 no. 204; Schwarb, Handbook, no. 498/1);3) Yahyā b. al-Ḥusayn b. al-Imām al-Qāsim (d. 1099/1688), al-Fawā’id 'alā l-Qalā’id (Ms Șan‘ā', $\operatorname{MJK}($ Š) 753, date: 1096/1685, Aḥmad 'Abd al-Razzāq al-Ruqayḥī, 'Abd al-Allāh al-Ḥibšī and 'Alī Wahhāb al-Ānsī, Fihrist Mahțūṭāt Maktabat al-Ğāmi' al-kabīr Șan'ā', 4 vols, Șanāà, Wizārat al-awqāf wa-l-iršād, 1404/1984 [hereafter cat. Ruqayhī], p. 699; AMZ, pp. 1111-1118 no. 1187. MFY, p. 720 no. 89; Schwarb, Handbook, no. 491/1-2).

See Ms London, British Library [hereafter BL], Or. 3937, f. 2a: ilam anna hād̄a l-kitāb al-ğalīl qad ištamala 'alā tis'a mutūn fìtis'a funūn. The same terminology is also used in the author's introduction, Or. 3937, f. 3a, ll. 4-12. The general introduction to Gंāyāt al-afkār is extant in MS BL Or. 3937, ff. 2b-22a. Sifr/asfär, by contrast, is used as a codicological unit.

MS BL Or. 3937, f. 2 b. 


\section{Ġāyāt al-afkārwa-nihāyāt al-anzāàr al-muḥita bi-ağāib al-Baḥr al-zahhhār}

\section{Underlying sections of $a l-B a h r$ al-zahhār, ${ }^{54}$ [ed. M.M. Tāmir, 6 vols, Beirut 1422/2001]}

\section{Muqaddima ${ }^{55}$}

1 K. al-Munya wa-l-amalfi šarh K. al-Milal wa-l-nihal ${ }^{56}$

2 K. al-Durar al-farāìd fì šarḥ K. al-Qalāì fì taṣhịh al-'aqā'id ${ }^{57}$

3 K. Dāmig̀ al-awhām fi šarh K. Riyāạat al-afhām fi lațîf al-kalām ${ }^{58}$

4 K. Minhāğ al-wuṣūlfí šarh (/ilā taḥqūq) K. Mi'yār al-'uqūlfí 'ilm al-uṣūl ${ }^{59}$

5 K. Yawāqüt al-siyar fi šarh K. al-Ğawāhir wa-l-durar fi Sirat Sayyid al-bašar wa-aṣhābihi al-'ašara al-g்urar wa-'itratihi l-a'imma al-muntahabin al-zuhar

6 K. al-Mustağād fi Šarh K. al-Intiqād li-l-āyāt al-mu'tabarafìl-iğtihād
K. al-Milalwa-l-nihal [vol. 1, pp. 26-51]

K. al-Qalāid fì taṣḥ̄ḥ al-'aqāid [vol. 1, pp. 52-113]

K. Rìādat al-afhām fi lațīfal-kalām [vol. 1, pp. 114-189]

K. Mi'yār al-'uqūlfì ìlm al-uṣūl [vol. 1, pp. 190-399]

K. al-Ǧawāhir wa-l-durar fi sìrat Sayyid al-bašar wa-aṣhābihi al-'ašr al-gंurar wa-'itratihi al-a'imma al-muntahabin al-zuhar [vol. 1, pp. 400-455] K. al-Intiqād li-l-āyāt al-mu'tabara fi l-iǧtihād [vol. 1, pp. 456-504]
7 K. Imād al-Islām fı̌ šarh hạà̄t K. al-Aḥkām al-mutaḍmmin li-fiqh a'immat al-Islām

8 K. al-Rawḍa al-naḍira fi šarh K. al-Durra al-munìra fi l-garīb min fiqh al-sìra

9 K. Šifä̀ al-asqām ${ }^{60}$ fi šarḥ K. al-Takmila li-l-aḥkām wa-l-tașfiya min bawātin al-ātām
K. al-Aḥkām al-mutadammin li-figh a’immat al-Islām [vol. 2, p. $5 \mathrm{ff}$.] K. al-Durra al-munïra fì l-garäb min fiqh al-sira [vol. 6, pp. 701-718] K. al-Takmila li-l-Ahkām wa-l-tasfiya min bawātin al-ātāam [vol. 6, pp. 719-765] ${ }^{61}$

Al-Baḥr al-zahhāer, Ġāyāt al-afkār, and many manuscripts of Mirqāt al-anz̄ār use acronyms (rumūz) to refer to the most important scholars (see ed. Tāmir, vol. 1, pp. 7-24).

55 See above n. $5^{2}$.

56 Ed. Muhammad Ğawād Maškūr, Beirut, Dār al-Fikr, 1979; besides, there are several independent editions of the well-known third part of K. al-Munya wa-l-amal (Bāb dikr alMu'tazila wa-țabaqātihim).

57 See the synoptic table of contents below.

$5^{8}$ See the synoptic table of contents below.

59 Ed. Aḥmad 'Alī Muṭahhar al-Māhuidhī, Șan'ā’, Dār al-Ḥikma al-Yamaniyya, 1412/1992.

6o Some manuscripts give the title as Tamarāt al-akmām.

61 Ed. 'Abd Allāh Ḥammūd Dirham al-'Izzī, 'Ammān, Mu’assasat al-Imām Zayd ibn 'Alī al-Taqāfiyya, 2002. 


\subsection{Manuscripts of K. Mirqāt al-anzāar ${ }^{62}$}

The central position of K. Mirqātal-anzār in the curriculum of Zaydì ușūl al-dīn studies is reflected in the significant number of extant manuscript copies. ${ }^{63}$ Only one manuscript dates from the 9 th/15th century (MS no. 2), six others from the 1oth/16th century (all dating before 959/1552). The vast majority (48) of the extant manuscripts date from the 11th/17th century, the first century of the Qāsimī dynasty, up to the copy date of Ms Munich, Bavarian State Library, Cod. arab. 1294 (1108/1696). Three manuscripts were copied around the middle of the 12th/18th century. No copy is extant from the period between $1172 / 1759$ (MS no. 57) and 1316/1898 (MS no. 66), followed by a copy from 1345/1926 (MS no. 32$) \cdot 64$

1. MS Berlin, State Library, Landberg 883 , ff. 1a-232b; date: ca. 1100/1688; W. Ahlwardt, Die Handschriftenverzeichnisse der königlichen Bibliothek zu Berlin, Siebenter Band: Verzeichnis der arabischen Handschriften, Berlin, A.W. Schade, 1887 ff. [hereafter cat. Ahlwardt], vol. 4, p. 311 no. 4911; W. Ahlwardt, Kurzes Verzeichnis der Glaser'schen Sammlung arabischer Handschriften, Berlin 1887 [hereafter cat. KV], p. $33 .{ }^{65}$

2. $\quad$ MS Berlin, State Library, Glaser 151; ff. 3a-198a; date: 877/1472; cat. Ahlwardt, vol. 4, p. 311 no. 4912/1; cat. KV, p. 27.

3. Ms Berlin, State Library, Glaser 194/5; ff. 33b-164b; date: Thur, 12 Rabī` II 1044/5 Oct 1634; cat. Ahlwardt, vol. 4, p. 312 no. 4912/2; cat. KV, p. 33.

4. Ms Berlin, State Library, Glaser 76; ff. 1a-144a; date: 1057/1647; cat. Ahlwardt, vol. 4, p. 312 no. 4912/3; cat. KV, p. 15 .

5. MS Berlin, State Library, Glaser 201/1; ff. 2a-115b; date: 1067/1657; cat. Ahlwardt, vol. 4, p. 312 no. 4912/4; cat. KV, p. 34 .

6. MS Milan, Ambrosiana, ar. A 40; ff. 146-233; date: 1042/1633; cat. Löfgren/Traini, vol. 2, p. 22 no. 40/II. ${ }^{66}$

62 This list of manuscripts is based on my Handbook, no. 435/1.

63 Significantly shorter lists are given in GAL, vol. 2, p. 239 ; GALS, vol. 2, p. 245 ; MFY, pp. 137-138; and the various manuscript catalogues.

64 See below n. 87.

65 The colophon on f. $232 b$ (Rağab 1159/July 1746) refers to the last four folios of the manuscript only.

66 Oscar Löfgren and Renato Traini, Catalogue of the Arabic Manuscripts in the Biblioteca Ambrosiana, 4 vols, Vicenza, Neri Pozza Editore (vols 1-3), Cinisello Balsamo (Milano), SilvanaEditoriale (vol. 4, ed. by R. Traini only) [vol. I: Antico Fondo and Medio Fondo, 1975; vol. II: Nuovo Fondo: Series A-D (Nos. 1-830), 1981; vol. III: Nuovo Fondo: Series E (Nos. 831-1295), 1995; vol. IV: Nuovo Fondo: Series F-H (Nos. 1296-1778), 2011. 
7. Ms Milan, Ambrosiana, ar. B 56; ff. 2-109; date:1071/1661; cat. Löfgren/Traini, vol. 2, p. 85 no. 180 .

8. MS Milan, Ambrosiana, ar. D 303; 173 ff.; date: 1001/1593; cat. Löfgren/Traini, vol. 2, p. 280 no. 559 .

9. MS Milan, Ambrosiana, ar. D 489/I; ff. 2-210; date: 1003/1594; cat. Löfgren/Traini, vol. 2, p. 374 no. $745 /$ I.

10. MS Milan, Ambrosiana, ar. E 132; ff. 4-65; date: 1043/1633; cat. Löfgren/Traini, vol. 3, p. 64 no. $962 /$ I.

11. MS Milan, Ambrosiana, ar. E 371/Add.a; ff. 224a-225a; date: 1077/1666; small extract only; cat. Löfgren/Traini, vol. 3, p. 150 no. 1201/Add.a.

12. MS Milan, Ambrosiana, ar. E 407/II; ff. 99-282; date: 1041/1632; cat. Löfgren/Traini, vol. 3, p. 165 no. 1237/II.

13. Ms Milan, Ambrosiana, ar. F 11; 121 ff.; date: 1083/1672; cat. Traini, vol. 4, p. 7 no. 1306.

14. MS Milan, Ambrosiana, ar. F 53; ff. 92-331; date: 1050/1640; cat. Traini, vol. 4, p. 21 no. 1348/II.

15. MS Milan, Ambrosiana, ar. F 77; ff. 1-205a; date: 1067/1656; cat. Traini, vol. 4, p. 33 no. 1372/I.

16. Ms Milan, Ambrosiana, ar. F 113; ff. 1-206; date: 1024/1615; cat. Traini, vol. 4, p. 53 no. 1408 .

17. MS Leiden, Universiteitsbibliotheek, Or. 6355/2; ff. 17-139a; date: 1054/ 1644-1645; Petrus Voorhoeve, Handlist of Arabic manuscripts in the library of the University of Leiden and other collections in the Netherlands, Leiden, Bibliotheca Universitatis, 1957, p. 39; Jan Just Witkam, Inventory of the Oriental Manuscripts of the Library of the University of Leiden; Volume 7: Manuscripts Or. 6001-700o, Leiden 2007, p. 139.

18. Ms London, British Library, Or. 6266/4; ff. 132-323; date: 1035/1626; extensive marginal glosses; A.G. Ellis and E. Edwards, A Descriptive List of the Arabic Manuscripts Acquired by the Trustees of the British Museum since 1894, London 1912, p. 14.

19. MS Munich, Bavarian State Library, Cod. arab. 1294 (formerly Cod. arab. Glaser 78); 111 ff.; date: 1108/1696; cat. Sobieroj, pp. 445-446 no. 234.

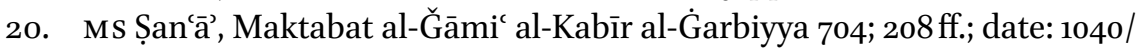
1631; cat. A.M. 'Īsawī et al., Fihris al-Mahțūțāt al-Yamaniyya li-Dār al-Mahțūțātwa-l-Maktaba al-Garbiyya bi-l-Jāmi'al-Kabìr, Șan'ā', Qum 1384šs/2005, p. $391 \mathrm{f}$.

21. MS Șan ‘̄à, Maktabat al-Ğāmic al-Kabīr al-Ġarbiyya 683; ff. 27-159; date: 1044/1635; cat. 'Īsawī, p. 392.

22. MS Șan'ā’, Maktabat al-Ğāmi` al-Kabīr al-Ġarbiyya 70o; 173 ff.; date of restoration: 1370/1951; cat. 'Īsawī, p. 392. 
23. MS Șanāā, Maktabat al-Ğāmi` al-Kabīr al-Ġarbiyya 696; ff. 7-239; date: 1100/1689; cat. ‘'̄sawī, p. 392.

24. MS Șan'ầ', Maktabat al-Ğāmi' al-Kabīr al-Ġarbiyya 705; 131ff.; cat. 'Īsawī, p. 392.

25. MS Șanāā, Maktabat al-Ğāmi' al-Kabīr al-Ġarbiyya 703; 311ff.; cat. 'Īsawī, p. 393 .

26. Ms Șanāà, Maktabat al-Ğāmi` al-Kabīr al-Ġarbiyya 701; 146 ff.; cat. 'Īsawī, p. 393 .

27. MS Șan`ā’, Maktabat al-Ğāmi` al-Kabīr al-Ġarbiyya 702; 264ff.; date: 1061/ 1651; cat. 'Īsawī, p. 393.

28. Ms Șan'ā’, Maktabat al-Ğāmi` al-Kabīr al-Garbiyya 706; 115ff.; date: 1103/ 1691; cat. 'T̄sawī, p. 393.

29. MS Șan`ā’’, Maktabat al-Ǧāmic al-Kabīr al-Ġarbiyya 707; 108ff.; date: 1086/ 1675; cat. 'Tsawī, p. 393.

30. Ms Șan'ā', Maktabat al-Ğāmi' al-Kabīr al-Ġarbiyya 708; 143 ff.; date: 1047/ 1637; cat. 'Īsawī, p. 393.

31. MS Șanāā, Maktabat al-Ğāmic al-Kabīr al-Garbiyya 709; ff. 6-112; date: 1154/1741; cat. Īsawī, p. 393 f.

32. MS Șan`ā', Maktabat al-Ğāmi al-Kabīr al-Ġarbiyya 710; 216 ff.; date: 1345/ 1926; cat. 'Īsawī, p. 394.

33. MS Șan'ā’, Maktabat al-Ǧāmi' al-Kabīral-Ġarbiyya 711; ff. 11-243; cat. 'T̄sawī, p. 394 .

34. MS Șan`ā’, Maktabat al-Ğāmic al-Kabīr al-Ġarbiyya 695; 146 ff.; date: 1023/ 1614; cat. 'Īsawī, p. 394.

35. MS Șanāă, Maktabat al-Ǧāmi` al-Kabīr al-Šarqiyya 177; ff. 75-290; date: 958/1551; cat. Ruqayhīi, p. 665 .

36. Ms Șanāā, Maktabat al-Ğāmic al-Kabīr al-Šarqiyya 589; ff. 5-150; date: 920/1514; cat. Ruqayhīi, p. 665 .

37. Ms Șan`ā’’ Maktabat al-Ğāmi` al-Kabīr al-Šarqiyya 719; 200 ff.; cat. Ruqayḥ̄i, p. 665 .

38. Ms Șan`ā’’, Maktabat al-Ğāmi` al-Kabīr al-Šarqiyya 723; 214ff.; date: 1047/ 1637; cat. Ruqayhìi, p. 740.

39. MS Șan`ā', Maktabat al-Ğāmic al-Kabīr al-Šarqiyya 722; 165 ff.; date: 10o1/ 1593; cat. Ruqayhịi, p. 741.

40. Ms Șan`ā’, Maktabat al-Ǧāmi` al-Kabīr al-Šarqiyya, Mağāamı̄‘ no. 2; ff. 1-87; date: 1014/1605; cat. Ruqayhīì, p. 741.

41. MS Șan`āà, Maktabat al-Ğāmi` al-Kabīr al-Šarqiyya 59o; 199 ff.; date: 1057/ 1647; cat. Ruqayhịi, p. 741.

42. MS Șan`ā', Maktabat al-Ğāmi` al-Kabīr al-Šarqiyya 737; 243ff.; date: 1051/ 1642; cat. Ruqayḥī, p. 742. 
43. MS Șan`ā', Maktabat al-Ǧāmi` al-Kabīr al-Šarqiyya 591; 151ff.; date: 1170/ 1756; cat. Ruqayhị, p. 742.

44. MS Șan'ā’, Maktabat al-Ǧāmi` al-Kabīr al-Šarqiyya 592; 139ff.; date: 1051/ 1641; cat. Ruqayhị, p. 742.

45. MS Șan'ā’, Maktabat al-Ǧāmi` al-Kabīr al-Šarqiyya 593; 130 ff.; cat. Ruqayḥ̄ī, 743.

46. MS Șan`ā’, Maktabat al-Ğāmi` al-Kabīr al-Šarqiyya 588; 195 ff.; cat. Ruqayḥī, 743.

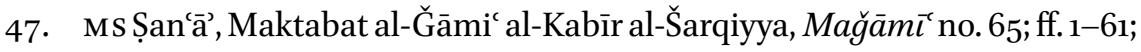
cat. Ruqayhīi, p. 743 .

48. MS Șan'ā’, Maktabat 'Abd Allāh b. Ismācil Ġimḍān; cat. FMMH̆, p. 13 no. 12.

49. Ms Șan'ā’’ Maktabat Muḥammad b. Yaḥyā b. 'Alī al-D̄ārī 81; date: 1075/ 1664-1665; cat. FMM H, p. 326 no. 786.

50. Ms Șan'ā’, Maktabat Muḥammad b. Muhammad Zabāra; cat. 'Abd Allāh Muḥammad al-Ḥibšī, "Mahutūṭāt Maktabat al-mu’arrih Muḥammad b. Muhạmmad Zabāra bi-Ṣanā̄”, RIMA (Mağallat machad al-mahțūtāt al'arabiyya) 19 i (1393/1973), p. 14 no. 40; cat. FMM H p. 206 no. 510.

51. MS Șan‘ā', Maktabat Muḥammad b. Muḥammad b. Ismācīl al-Muțahhar (/al-Manșūr); 107 ff.; date: 925/1519; cat. "al-Mahțūṭāt allatī șawwarathā bu'tat al-Ma'had ilā l-Ǧumhūriyya al-'Arabiyya al-Yamaniyya, 29/o7-2/12/ 1974," RIMA (Mağallat machad al-mahțūțāt al-'arabiyya) 22 i (1396/1976), p. 54 no. 341; cat. FMMH, p. 378 no. 903 .

52. MS Șan'ā’, Maktabat Muhammad b. Muḥammad al-Kibsī; date: 1070/166o; cat. мтмнुY, vol. 1, p. 196 no. 13 .

53. MS Șan'ā’, Maktabat Muhammad b. Muhammad al-Kibsī; date: 1025/1616; cat. мтмHy, vol. 1, p. 196 no. 14/1; $; 67$ =(?)IZbACF CD no. 279/3; $232 \mathrm{ff}$.

54. MS Șan‘ā’, Maktabat Muhammad b. Muḥammad al-Kibsī; date: 1062/1652; cat. мтмHy, vol. 1, p. 198 no. 18/1.

55. Ms Șan'ā’, Maktabat Muḥammad b. Muhammad al-Kibsī; date: 1095/1684; cat. мтмHY, vol. 1, p. 239 no. 100.

56. MS Șan‘ā’, Maktabat Yahyyā b. Muhammad b. 'Alī b. Ismāēil al-Mutawakkil; date: 1094/1683; cat. MTM HुY, vol. 1, p. 284 no. 14; IZbACF CD no. 431/2.

57. MS Șa‘da, Maktabat Āl al-Hāšimī; date:1172/1759; cat. M TMHુY, vol. 1, p. 349 no. $98 / 2$.

67 The catalogue gives the title as Mirqāt al-anzār al-muntaza' min Ġāyat al-afkār al-kāšif li-ma'āni muqaddimat al-Azhār. This is likely to be a cataloguing error. A Šarh on the muqaddima of al-Mahdī's K. al-Azhār with the title "Mirqāt al-anzāa" was authored by Ṣalāḥ b. 'Alī al-Miḍwāhịi (d. after 1007/1598-1599; MB, vol. 2, p. 491). See above n. 50. 
58. MS Ṣa da, Maktabat Āl al-Hāšimī; date:1075/1664-1665; cat. MTM HyY, vol. 1, p. 364 no. 176/5; MF Ḍahyān, Maktabat Muḥammad b. 'Abd al-'Aẓīm alHādī; cat. M TM MuY, vol. 1, p. 541 no. 504/1; MF Șan'ā’’, Maktabat Markaz Badr al-'Ilmī wa-l-Taqāfí; date: 1075/1664-1665; cat. M M MHY, vol. 1, p. 256 no. 14; IZbACF CD no. 375/4.

59. Ms Ṣacda, Maktabat Āl al-Hāšimī; date: 953/1546; cat. M TMHูY, vol. 1, p. 365 no. $177 / 2$.

6o. Ms Șađda, Maktabat Āl al-Hāšimī; date:1062/1652; cat. M TMHูY, vol. 1, p. 368 no. $188 / 1$.

61. Ms Șa'da, Maktabat Āl al-Hāšimī; date: 949/1542; cat. M TMHYY, vol. 1, p. 385 no. 267/6; IZbACF CD no. 178/3.

62. MS Hiğrat Falalla, Maktabat Sirāğ al-Dīn 'Adlān; microfilm; date: 1084/ 1673; cat. MTMHY, vol. 2, p. 55 no. 1.

63. Ms Ḍahyān, Maktabat Muḥammad b. al-Ḥasan al-Q̣asimī; cat. мтмн̣Y, vol. 2, p. 186 no. 46.

64. M M Șa‘da, Maktabat Muḥammad b. al-Ḥasan al-Ḥūtīi cat. MTм H̦Y, vol. 2, p. 197 no. 27.

65. MS Ṣacda, Maktabat Mazār al-Imām Yahyāā b. Ḥusayn al-Hādī ilā l-Ḥaqq; 117 ff.; cat. M TMHY, vol. 2, p. 454 no. 21; cat. 'Izzī, p. 27 no. 12.

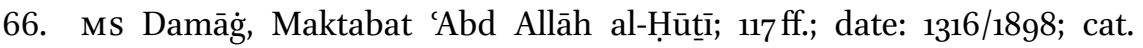
MTMHY, vol. 2, p. 559 no. 10; IZbACF CD no. 361/2.

67. MS Šahāra, Maktabat Madīnat Šahāra; date: cat. MTMHูY, vol. 2, p. 617 no. 70.

68. Ms Vienna, Austrian National Library, Cod. ar. 126 (formerly Glaser 183); date: 1050/1640-1641; cat. Grünert, p. 36 no. 128.

69. MS Vienna, Austrian National Library, Cod. ar. 187 (formerly Glaser 13); date: 1048/1638-1639; cat. Grünert, p. 36 no. 129.

70. Ms Vienna, Austrian National Library, Cod. ar. 177 (formerly Glaser 84); date: ca. 1050/1640; cat. Grünert, p. 30 no. 94.

The location of the original manuscripts of the following reproductions has not yet been ascertained: 68

68 Over the last decades and especially during the Șa'da wars hundreds of Zaydī manuscripts have found their way to private and public collections in Saudi Arabia, often by way of illicit trading. Public libraries and research institutes with Zaydī manuscripts include the King Abdullah Ibn Abdulaziz Library at the Umm al-Qura University in Mecca (uqu.edu .sa/lib/digital_library/), the King Saud University (http://makhtota.ksu.edu.sa), the Imam Muhammad Ibn Saud Islamic University (http://library.imamu.edu.sa/), and the King Faisal Center for Research and Islamic Studies (http://www.kff.com/). 
71. Ms Mecca, Umm al-Qura University 13727-1; date:Jumādā I 1073/Dec 1662.

72. Ms Mecca, Umm al-Qura University 13253.

73. Ms Mecca, Umm al-Qura University 13772-1.

74. MS IZbACF CD no. 95/5; 121 ff.; date: 1077/1667.

75. MS IZbACF CD no. $239 / 3$; n.d.

76. MS IZbACF CD, no. 395/3; 217 ff.; date: 921/1515; = Mecca, Umm al-Qura University 13251.

77. Ms IZbACF CD no. 576/2; date: 1074/1664.

2.2.1 Structure of K. al-Qalā'id, K. al-Durar al-farā'id and K. Mirqāt al-anzār

\begin{tabular}{|c|c|c|c|}
\hline Chapter headings 69 & 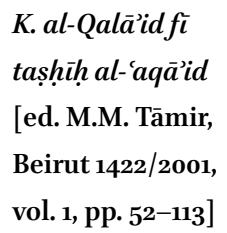 & $\begin{array}{l}\text { al-Durar al-farā'id } \\
(=a l-f a n n \text { al-țānī min } \\
\text { Kitāb Ġāyāt al-afkār) }\end{array}$ & $\begin{array}{l}\text { Mirqāt al-anzāār } \\
\text { [MSs B L Or. 6266; } \\
\text { Munich, Cod. arab. 1294] }\end{array}$ \\
\hline $\begin{array}{l}\text { Muqaddimat K. al-Durar } \\
\text { al-farā’id ( } 4 \text { fușūl) }\end{array}$ & & $\begin{array}{l}\text { вL Or. } 3956, \text { f. } 1 b-4 b \\
\text { вL Or. } 3937,{ }^{70} \text { f. } 64 a-66 a\end{array}$ & \\
\hline $\begin{array}{l}\text { Faṣl al-'ilm 'alā sabīl } \\
\text { al-ğumla } \\
\text { Faṣl hāọāa al-fann 'alā sab } \\
\text { al-huușūṣ }\end{array}$ & & $\begin{array}{l}\text { BL Or. } 3956, \text { f. } 1 b-2 b \\
\text { BL Or. } 3937, \text { f. } 64 a-65 a\end{array}$ & \\
\hline $\begin{array}{l}\text { Bayān mā warada fì } \\
\text { l-Kitāb wa-l-Sunna min } \\
\text { al-hawḍ fí 'ilm al-kalām } \\
\text { wa-l-ḥatt 'alayhi }\end{array}$ & - & $\begin{array}{l}\text { BL Or. } 3956 \text {, f. } 2 \mathrm{~b}-3 \mathrm{a} \\
\text { BL Or. } 3937, \text { f. } 65 \mathrm{a}\end{array}$ & - \\
\hline
\end{tabular}

69312 masāil in total. According to Ms Milano, Biblioteca Ambrosiana, ar. E 407/II; ff. $97 \mathrm{a}$ and 98a-b, cat. Löfgren, vol. 3, p. 165 no. 1237/II, K. Mirqāt al-anzāär comprises 183 masā̄il only.

70 Cat. Rieu, p. 246f. no. 410; Ḥusayn 'Abd Allāh al-Amrī, Maṣādir al-turāt al-yamañ̄ fì l-Mathaf al-Barịṭānī, Damascus, Dār al-Muhtār, 1400/1980 [hereafter мту], pp. 215-217 no. 410. 


\begin{tabular}{|c|c|c|c|}
\hline Chapter headings & $\begin{array}{l}\text { K. al-Qalā’id fì } \\
\text { taṣḥị̣ al-'aqā'id } \\
\text { [ed. M.M. Tāmir, } \\
\text { Beirut 1422/2001, } \\
\text { vol. 1, pp. 52-113] }\end{array}$ & 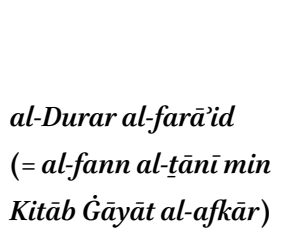 & $\begin{array}{l}\text { Mirqāt al-anzāarr } \\
\text { [MSs BL Or. 6266; } \\
\text { Munich, Cod. arab. 1294] }\end{array}$ \\
\hline $\begin{array}{l}\text { Mā warada 'an al-Ṣahāba } \\
\text { fíl-'adl wa-l-tawhìd } \\
\text { wa-l-wa'd wa-l-wa'ìd } \\
\text { wa-d̄amm al-mubtadi'a } \\
\text { wa-ta'yīnihim }\end{array}$ & & $\begin{array}{l}\text { вL Or. } 3956, \text { f. } 3 a-4 a \\
\text { BL Or. } 3937, \text { f. } 65^{a-65 b}\end{array}$ & \\
\hline $\begin{array}{l}\text { Tayiñn al-qadr al-wāğib } \\
\text { ma'rifatuhu min hād̄a } \\
\text { l-ilm }\end{array}$ & & $\begin{array}{l}\text { BL Or. } 3956, \text { f. } 4 a-4 b \\
\text { BL Or. } 3937, \text { f. } 65 \text { b- } 66 a\end{array}$ & \\
\hline Kitāb al-Tawḥ̄d (45 masāìl) & $5^{2-61}$ & $\begin{array}{l}\text { вL Or. } 3956 \text {, f. } 4 \text { b-117a } \\
\text { BL Or. } 3937 \text {, f. } 66 a-138 a\end{array}$ & $\begin{array}{l}\text { BL Or. } 6266 \text {, f. } 132 b-176 b \\
\text { Munich } 1294 \text {, f. } 1 b-25 a\end{array}$ \\
\hline Muqaddima (7 masā'il) & $5^{2-54}$ & $\begin{array}{l}\text { вL Or. } 3956, \text { f. } 4 \text { b-30a } \\
\text { вL Or. } 3937 \text {, f. } 66 a-82 a\end{array}$ & $\begin{array}{l}\text { BL Or. } 6266 \text {, f. 132b-144a } \\
\text { Munich 1294, f. 1b-5b }\end{array}$ \\
\hline Faṣlfı șifātihi (23 masā̉il) & $54-59$ & $\begin{array}{l}\text { вL Or. } 3956 \text {, f. } 30 a-105 b \\
\text { вL Or. } 3937 \text {, f. } 82 a-130 b\end{array}$ & $\begin{array}{l}\text { BL Or. } 6266 \text {, f. } 144 a-167 a \\
\text { Munich 1294, f. } 5^{b-19 b}\end{array}$ \\
\hline $\begin{array}{l}\text { Fașl fíl-asmā' } \\
\text { wa-ma'ānīhā (15 masā’il) }\end{array}$ & $59^{-61}$ & $\begin{array}{l}\text { BL Or. } 3956 \text {, f. } 105^{b}-117 b \\
\text { BL Or. } 3937 \text {, f. } 130 b-138 a\end{array}$ & $\begin{array}{l}\text { BL Or. } 6266 \text {, f. } 167 a-176 a \\
\text { Munich 1294, f. 19b-25a }\end{array}$ \\
\hline Kitāb al-'Adl (103 masā̄il) & $62-80$ & $\begin{array}{l}\text { BL Or. } 3956 \text {, f. 117b-end } \\
\text { BL Or. } 3937 \text {, f. } 138 \text { a-end }\end{array}$ & $\begin{array}{l}\text { BL Or. } 6266 \text {, f. } 176 b-225 \text { b } \\
\text { Munich } 1294 \text {, f. } 25^{a-54 b}\end{array}$ \\
\hline Muqaddima (7 masā’il) & $62-63$ & $\begin{array}{l}\text { BL Or. } 3956 \text {, f. } 117 \mathrm{~b}-135^{b} \\
\text { BL Or. } 3937 \text {, f. } 138 \mathrm{a}-15 \mathrm{ob}\end{array}$ & $\begin{array}{l}\text { BL Or. } 6266 \text {, f. } 176 b-181 b \\
\text { Munich 1294, f. } 25 a-28 a\end{array}$ \\
\hline Fașl fíl-irāda (6 masā̄il) & $63^{-64}$ & $\begin{array}{l}\text { вL Or. } 395^{6} \text {, f. } 135^{b-147 b} \\
\text { вL Or. } 3937 \text {, f. } 150 b-15^{8 b}\end{array}$ & $\begin{array}{l}\text { BL Or. } 6266 \text {, f. } 181 b-184 b \\
\text { Munich 1294, f. } 28 a-30 a\end{array}$ \\
\hline
\end{tabular}


(cont.)

\begin{tabular}{|c|c|c|c|}
\hline Chapter headings & $\begin{array}{l}\text { K. al-Qalā'id fì } \\
\text { taṣhüḥal-'aqā̄id } \\
\text { [ed. M.M. Tāmir, } \\
\text { Beirut 1422/20o1, } \\
\text { vol. 1, pp. 52-113] }\end{array}$ & 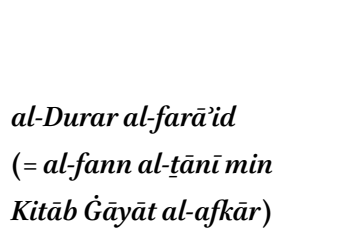 & $\begin{array}{l}\text { Mirqāt al-anzāār } \\
\text { [MSs BL Or. 6266; } \\
\text { Munich, Cod. arab. 1294] }\end{array}$ \\
\hline Faṣlfiıl-kalām (4 masā̉il) & $64-65$ & $\begin{array}{l}\text { вL Or. } 3956 \text {, f. } 147 b-156 a \\
\text { BL Or. } 3937 \text {, f. } 158 b-164 a\end{array}$ & $\begin{array}{l}\text { BL Or. } 6266 \text {, f. 184b-187a } \\
\text { Munich 1294, f. 30a-31b }\end{array}$ \\
\hline $\begin{array}{l}\text { Fașlfí halq al-af'äl (22 } \\
\text { masā’il) }\end{array}$ & $65^{-68}$ & $\begin{array}{l}\text { вL Or. } 3956 \text {, f. } 156 a-195^{b} \\
\text { вL Or. } 3937 \text {, f. } 164 a-189 b\end{array}$ & $\begin{array}{l}\text { BL Or. } 6266 \text {, f. } 187 a-196 b \\
\text { Munich 1294, f. } 31 b-38 a\end{array}$ \\
\hline $\begin{array}{l}\text { Fașlfíl-ağal wa-l-rizq (29 } \\
\text { masāill) }\end{array}$ & $68-74$ & $\begin{array}{l}\text { BL Or. } 3956 \text {, f. } 195^{b-243^{71}} \\
\text { BL Or. } 3937 \text {, f. } 189 b-221 a^{72}\end{array}$ & $\begin{array}{l}\text { BL Or. 6266, f. 196b-211a } \\
\text { Munich 1294, f. } 38 a-46 b\end{array}$ \\
\hline Faṣlfíl-alțāf (15 masāil) & $75^{-77}$ & $\begin{array}{l}{\left[\mathrm{MĞK}(\check{\mathrm{s}}) 5^{85}, 5^{86}, 576\right]} \\
(\text { not seen })^{73}\end{array}$ & $\begin{array}{l}\text { BL Or. } 6266 \text {, f. } 211 a-218 b \\
\text { Munich 1294, f. } 46 b-50 b\end{array}$ \\
\hline $\begin{array}{l}\text { Fașlfíl-ālām (17 masāill) } \\
\text { [Faṣlfíl-'iwaḍ] }\end{array}$ & $78-80$ & MĞK $(\breve{s}) 585$ (not seen) & $\begin{array}{l}\text { BL Or. } 6266 \text {, f. } 218 b-224 b \\
\text { Munich 1294, f. } 5 \text { ob-54a }\end{array}$ \\
\hline $\begin{array}{l}\text { Fașl fì masāil mutafarriqa } \\
\text { (3 masā'il) }\end{array}$ & 80 & MĞK(ك̌) 585 (not seen) & $\begin{array}{l}\text { BL Or. } 6266 \text {, f. } 224 b-225 \text { b } \\
\text { Munich 1294, f. } 54 a-54 b\end{array}$ \\
\hline
\end{tabular}

71 MS BL Or. 3956, f. 243a: tamma al-sifr al-awwal min Kitāb al-Durar al-farā̉id fı̌ šarh Kitāb al-Qalā'id. Sifr is here a codicological unit [al-sifr al-awwal min Kitāb al-Durar $=a l$-sifr al-țānī min Ġāyāt al-afkār].

72 MS BL Or. 3937, f. 221a: tamma al-ğuz' al-awwal min ğuz'ayn min Kitāb al-Durar al-farā’id fi šarh Kitāb al-Qalā̉id [...]. Yatlühu faṣlun fì l-alțāâ.

73 Here starts the third sifr resp. the second part of al-Durar al-farā’id. See Maktabat al-Ğāmic al-Kabīr al-Šarqiyya 585, cat. Ruqayhị, pp. 612-613; al-Kamālī, al-Imām al-Mahdī, pp. 131133.

74 The section on 'iwad is introduced as a separate fașl (MS BL Or. 6266, f. $221 \mathrm{~b}=$ Ms Bavarian State Library, Cod. arab. 1294, f. 52a). 


\begin{tabular}{|c|c|c|c|}
\hline Chapter headings & $\begin{array}{l}\text { K. al-Qalāid fì } \\
\text { tașhīḥ al-'aqā'id } \\
\text { [ed. M.M. Tāmir, } \\
\text { Beirut 1422/2001, } \\
\text { vol. 1, pp. 52-113] }\end{array}$ & $\begin{array}{l}\text { al-Durar al-farāid } \\
\text { (=al-fann al-țānī min } \\
\text { Kitāb Ġāyāt al-afkār) }\end{array}$ & $\begin{array}{l}\text { Mirqāt al-anzāàr } \\
\text { [MSs BL Or. 6266; } \\
\text { Munich, Cod. arab. 1294] }\end{array}$ \\
\hline $\begin{array}{l}\text { Kitāb al-Nubuwwāt wa-mā } \\
\text { yata'allaqu bi-hā (29 masā'il) }\end{array}$ & $81-86$ & MĞK( $\dot{\mathrm{G}}) 747$ (not seen) & $\begin{array}{l}\text { BL Or. } 6266 \text {, f. } 225 \text { b-239a } \\
\text { Munich 1294, f. } 54 b-63 a\end{array}$ \\
\hline $\begin{array}{l}\text { Kitāb al-Wa'd wa-l-wa'id ( } 68 \\
\text { masā'il) }\end{array}$ & $87-99$ & MĞK( $\dot{\mathrm{G}}) 747$ (not seen) & $\begin{array}{l}\text { BL Or. } 6266 \text {, f. } 239 a-281 a \\
\text { Munich 1294, f. } 63^{a}-87 a\end{array}$ \\
\hline Muqaddima (11 masāill) & $87-88$ & MĞK $(\dot{\mathrm{G}}) 747$ (not seen) & $\begin{array}{l}\text { BL Or. } 6266 \text {, f. } 239 a-243 b \\
\text { Munich 1294, f. } 63^{a}-65^{b}\end{array}$ \\
\hline $\begin{array}{l}\text { Faṣl fíl-muwāzana } \\
\text { wa-l-iḥbātwa-māa } \\
\text { yata'allaqu bi-himā (46 } \\
\text { masāill) }\end{array}$ & $89-96$ & MĞK( $\dot{\mathrm{G}}) 747$ (not seen) & $\begin{array}{l}\text { BL Or. } 6266 \text {, f. } 243 \text { b-271a } \\
\text { Munich 1294, f. } 65 \text { b-81b }\end{array}$ \\
\hline $\begin{array}{l}\text { Faṣl fí l-asmāà al-šar'iyya } \\
\text { wa-mā yata'allaqu bi-hā } \\
\text { (11 masā'il) }\end{array}$ & $97-99$ & MĞK( $\dot{\mathrm{G}}) 747$ (not seen) & $\begin{array}{l}\text { вL Or. 6266, f. 271a-281a } \\
\text { Munich 1294, f. 81b-87a }\end{array}$ \\
\hline
\end{tabular}

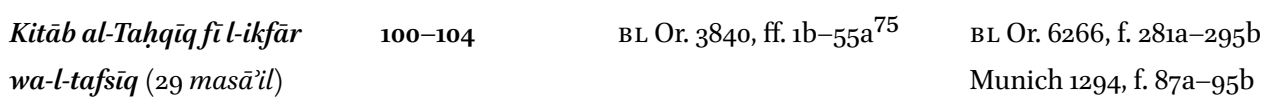

Muqaddima (3 fușūl)

al-Kalām 'alā masā̉il hādā

l-kitāb (-masā̉il)

Hūtima yuhtam ${ }^{76}$ bi-hā

hā $\underline{\text { à }}$ l-kitāb (-masā̄il)
BL Or. 3840 , ff. $1 \mathrm{~b}-4 \mathrm{a}$

BL Or. 3840 , ff. $4 a-52 b$

BL Or. 3840 , ff. $5^{2 b-55^{a}}$

75 MS BL Or. 3840 (= Glaser 128); 177 ff.; date: $1174 / 1760$; cat. Rieu, p. 250 no. 417; MTY, pp. 209210 no. 417.

76 Ms tahtim. 
(cont.)

\begin{tabular}{|c|c|c|c|}
\hline Chapter headings & $\begin{array}{l}\text { K. al-Qalä’idfi } \\
\text { taṣḥịh al-'aqā'id } \\
\text { [ed. M.M. Tāmir, } \\
\text { Beirut 1422/2001, } \\
\text { vol. 1, pp. 52-113] }\end{array}$ & $\begin{array}{l}\text { al-Durar al-farāìd } \\
\text { (=al-fann al-țānī min } \\
\text { Kitāb Ġāyāt al-afkār) }\end{array}$ & $\begin{array}{l}\text { Mirqāt al-anzāār } \\
\text { [MSS BL Or. 6266; } \\
\text { Munich, Cod. arab. 1294] }\end{array}$ \\
\hline Kitāb al-Imāma (38 masāill) & $105^{-113}$ & вL Or. 3840, ff. $55^{a-176 b}$ & $\begin{array}{l}\text { BL Or. } 6266 \text {, f. } 295^{b}-323 b \\
\text { Munich 1294, f. } 95^{b-111 a}\end{array}$ \\
\hline Muqaddima (27 masā̄il) & $105^{-110}$ & вL Or. 3840 , ff. $55^{a-16 o a}$ & $\begin{array}{l}\text { BL Or. } 6266, \text { f. } 295^{b}-315^{a} \\
\text { Munich } 1294 \text {, f. } 95^{b-106 b}\end{array}$ \\
\hline $\begin{array}{l}\text { Faṣl fì l-amr bi-l-ma'rūf } \\
\text { wa-l-nahy 'an al-munkar } \\
(7 \text { masā'il) }\end{array}$ & $111-112$ & BL Or. 3840 , f. $160 a-167 b$ & $\begin{array}{l}\text { BL Or. } 6266 \text {, f. } 315^{a-319 b} \\
\text { Munich 1294, f. 106b-108b }\end{array}$ \\
\hline $\begin{array}{l}\text { Fașlfì l-dār wa-aḥkāmihā } \\
(4 \text { masāंil) }\end{array}$ & $112-113$ & BL Or. 3840 , ff. $167 b-176 b^{77}$ & $\begin{array}{l}\text { BL Or. } 6266 \text {, f. } 319 b-323 b \\
\text { Munich 1294, f. 108b-111a }\end{array}$ \\
\hline
\end{tabular}

Other manuscripts of K. al-Durar include (selection only): (a) Milan, Ambrosiana, ar. E 54; ff. 51b-183; the first section only: K. al-Tawhìd (53b-), K. al-Adl (112b-); cat. Löfgren/Traini, vol. 3, p. 26 no. 884.-(b) Milan, Ambrosiana, ar. E 6o; ff. 52b-178; date: 866/1462; the first section only: $K$. al-Tawhìd (53b-), $K$. al-'Adl (109a-); cat. Löfgren/Traini, vol. 3, p. 29 no. 890.-(c) London, BL, Or. 3956 (= Glaser 250); 243 ff.; date: 836/1433; the first section only: $K$. al-Tawhid (4b-), K. al-'Adl (117b-); cat. Rieu, pp. 249-250 no. 415; MTY, p. 208 no. 415.-(d) London, BL, Or. 4020 (= Glaser 322); 207 ff.; date: 10th/16th cent.; the first section only: K. al-Tawhïd (3b-), K. al-'Adl (104a-); cat. Rieu, p. 250 no. 416; MTY, pp. $208-$ 209 no. 416.-(e) London, BL, Or. 3840 (= Glaser 128); 177 ff.; date: 1174/176o; comprises K. al-Tahqū̃ fì l-ikfär wa-l-tafsīq (1-54), and K. al-Imāma (55-177); cat. Rieu, p. 250 no. 417; MTY, pp. 209-210 no. 417.-(f) Șanāa), MĞK(ك̌) 2400; 397 ff.; vol. 2 (beginning with fașl fi halq al-af'äl); date: 1090/1679; cat. Ruqayhịi,

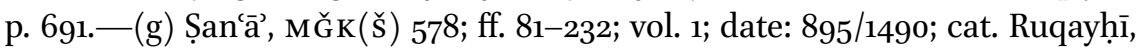

77 MS BL Or. 3840, f. 177a: tamma šarh al-muqaddimatayn al-awwalatayn min muqaddimāt Kitāb al-Bahr al-zahhār al-ğāmic li-mad̄āhib 'ulamā’ al-amșār [...]. wa-lammā farag̉nā min

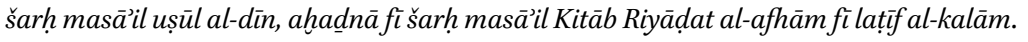




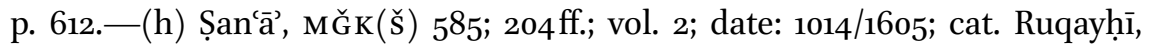

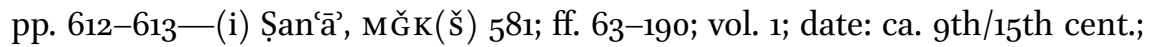

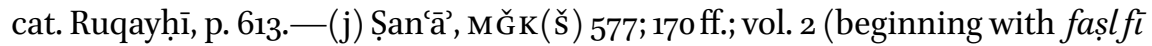
l-alțāf); date: 867/1463; cat. Ruqayhī, pp. 613-614-(k) Șan`ā', M ĞK( š) 579;ff. 81-

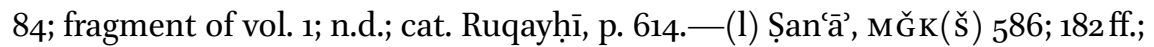
vol. 2; date: 887/1482; cat. Ruqayhịi, pp. 614-615-(m) Șan`ā', MĞ K(

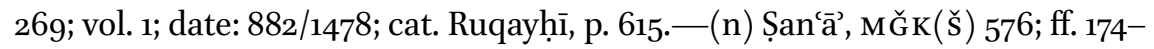
269; vol. 2 (beginning with fașl fi l-alțāf); date: 1068/1657; cat. Ruqayhīi, pp. 615616-(o) Șan`ā’, M ĞK ( $\dot{\mathrm{G}}) 746$ (formerly Ușülal-dìn no. 112); ff. 62-254; vol. 1; date: 872/1467; cat. 'Īsawī, pp. 305-306; cat. RIMA 22 (1976), p. 34 no. 211.—(p) Șanăà,

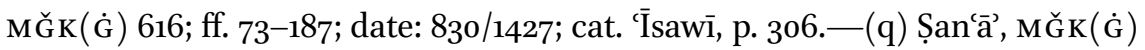
747; ff. 68-490; vols 1-2 (a complete copy of K. al-Durar); cat. '̄isawī, p. 306.-

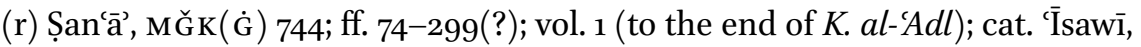

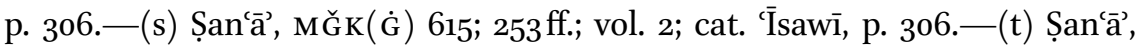

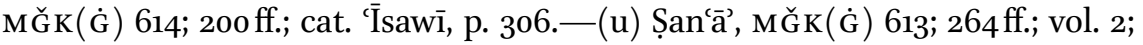
date: 1064/1654; cat. 'Īsawī, p. 307.-(v) Șan`ā', MĞ K( $\dot{\mathrm{G}})$ 612; 225 ff.; vol. 1; date: 980/1573; cat. 'İsawī, p. 307.- (w) Șan'à', Maktabat Muḥammad b. Muḥammad al-Kibsī; date: 1034/1625; cat. MTM HuY, vol. 1, p. 223 no. 59/2.—(x) Mecca, Umm al-Qura University 12041; date: 1078/1667; IZbACF CD no. 165/2.

2.2.2

Structure of K. Riyā dat al-afhām, K. Dāmig̀ al-awhām, Ibn Mattawayh's K. al-Tadkira and al-Ḥākim al-Ǧišumì's Šarḥ 'Uyūn al-masāil (part x)

The structure of K. Dāmig̀ al-awhām and K. Riyā dat al-afhām fì lațîf al-kalām reflects the convergence of two distinct Bahšamī traditions of lațîfal-kalām, one represented by Ibn Mattawayh's K. al-Tad̂lkira fì ahkām al-ğawāhir wa-l-ärād, the other by the tenth part of al-Ḥākim al-Ǧišumì's Šarḥ 'Uyūn al-masāill. While the main part of K. Dāmig al-awhām (up to the end of Bāb al-idrāk) is named "Šarh al-Tadkira", it follows the chapter order of Šarḥ 'Uyūn al-masāil.

Other manuscripts of K. Dāmig al-afhām include (selection only): (a) Vienna, Austrian National Library, Cod. ar. 79 (= Glaser 165); date: 838/1434-1435; cat. Grünert, p. 19 no. 42. - (b) Munich, Bavarian State Library, Cod. ar. 1249; ff. 64b-

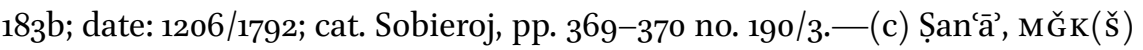

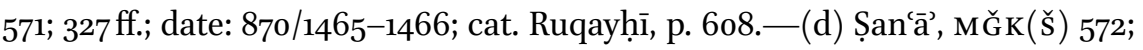
19o ff.; date: 881/1476-1477; cat. Ruqayhị, p. 6o8; cat. RIMA 22 (1976), p. 14 no. 76 [with old no. "221"].-(e) Șan'ā', MĞK( š) 573; $341 \mathrm{ff.;} \mathrm{date:} \mathrm{850/1446-1447;} \mathrm{cat.}$ Ruqayhīi, p. 6og.-(f) Șan'ā’, MĞK( (̌) 574; 146 ff.; date: 877/1472-1473; cat. Ruqay-

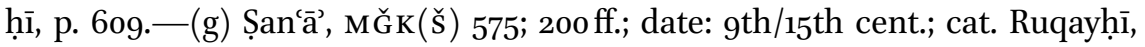
p. 6o9.-(h) Qum, Mar'ašì 11913; date: 887/1482; cat. vol. 30, pp. 196 -197 no. 196.-(i) Mecca, Umm al-Qura University 13065, 2 vols, date: 910/ 


\begin{tabular}{|c|c|c|c|c|}
\hline $\begin{array}{l}\text { K. Riyāẹat al-afhām } \\
\text { (442 masā’il) } \\
\text { [ed. M.M. Tāmir, Beirut } \\
\text { 1422/2001, vol. 1, pp. 114-189] }\end{array}$ & $\begin{array}{l}\text { K. Dāmig̀ } \\
\text { al-awhām }^{78} \\
{[\text { MS вL Or. }} \\
\text { 3807 }^{79}\end{array}$ & $\begin{array}{l}\text { Ibn Mattawayh, } \\
\text { K. al-Tad dkira } \\
\text { [ed. D. Gimaret] }\end{array}$ & $\begin{array}{l}\text { Šarḥ al-Taďdkira } \\
\text { [Ms Tehran, } \\
\text { Mahdavi }{ }_{514}{ }^{80}\end{array}$ & $\begin{array}{l}\text { [Mss Riyadh, } \\
\text { Ǧāmi'at al-Malik } \\
\text { Sa'ūd 7783; } \\
\text { (IZbACF CD } \\
\text { no. 362:2)] }\end{array}$ \\
\hline Muqaddima $[-]$ & $1 b-5 b$ & $1-8$ & $\mathrm{lb}[2]-3 \mathrm{~b}[6]$ & $1 b$ \\
\hline $\begin{array}{l}\text { Bāb al-ğawāhir (45 masā’il) } \\
{[114-122]}\end{array}$ & $5^{b-33 b}$ & $9-73$ & $3 \mathrm{~b}[6]-27 \mathrm{~b}[54]$ & $3^{a}$ \\
\hline $\begin{array}{l}\text { Bāb al-fanā' (8 masāìl) } \\
{[122-123]}\end{array}$ & $33^{b-38 a}$ & $101-123$ & $33 \mathrm{~b}[66]-39 \mathrm{a}[77]$ & $40 a$ \\
\hline $\begin{array}{l}\text { Bāb al-a'rād 'alā l-ğumla }(9 \\
\text { masā'il) [124-126] }\end{array}$ & $3^{8 a}-40 b$ & 125 & $39 a[77]$ & $46 b(1 b)$ \\
\hline $\begin{array}{l}\text { Bābal-alwān (11 masāìl) } \\
{[127-128]}\end{array}$ & $40 b-47 a$ & $127-15^{2}$ & $39 \mathrm{a}[77]-45 \mathrm{~b}[9 \mathrm{o}]$ & $49 a(3 b)$ \\
\hline $\begin{array}{l}\text { Bāb al-țu'üm wa-l-rawāìh }(1 \\
\text { mas'ala) [128] }\end{array}$ & $47 a-48 b$ & $153^{-155,157}$ & $45 \mathrm{~b}[90]-46 \mathrm{~b}\left[9^{2}\right]$ & $57 \mathrm{a}(9 \mathrm{~b})$ \\
\hline $\begin{array}{l}\text { Bāb al-harāra wa-l-burūida (4 } \\
\text { masā’il) [129] }\end{array}$ & $48 b-50 a$ & $159^{-161}$ & $46 \mathrm{~b}\left[9^{2}\right]-48 \mathrm{a}[95]$ & $5^{8 \mathrm{~b}(1 \mathrm{ob})}$ \\
\hline
\end{tabular}

78 In MS BL Or. 3807 (cat. Rieu, $250-251$ no. 418 ; мту, p. 210 no. 418 ), f. 256 b the end date of composition (ta'līf) of K. Dāmig̀ al-awhām was Friday, 8 Rağab 828 (26 May 1425). According to мв Ibn Yahyyā al-Murtaḍā completed K. al-Durar and wrote K. Dāmig al-awhām up to Bāb al-itiqāed during his stay in Miswar, and completed the work in Qal'at Abī Yazīd. See Muhammad Muhammad al-Ḥāğğ Ḥasan al-Kamāīì, al-Imām al-Mahdī A ḥmad b. Yahyā l-Murtaḍa wa-ațaruhu fì l-fikr al-islāmī siyāsiyyan wa-'aqā̉idiyyan, Șan'ā’, Dār al-Ḥikma al-Yamāniyya, 1411/1991, p. 115.

79 K. Dāmig al-awhām is at times introduced as al-sifr al-hāmis min Ġāyāt al-afkār. In these cases K. al-Munya comprises one sifr (1), K. al-Durar three asfär (2-4). Just as in MS BL Or. 3956 sifr refers to a codicological unit.

8o A facsimile edition of the manuscript was published by the Iranian Institute of Philosophy and the Institute of Islamic Studies at Freie Universiät Berlin, Tehran 2006. 


\begin{tabular}{|c|c|c|c|c|}
\hline K. Riyādat al-afhām & $\begin{array}{l}\text { K. Dāmig } \\
\text { al-awhām }\end{array}$ & Tadkira & Šarḥ al-Tadkira & $\begin{array}{l}\text { Šarh 'Uyūn } \\
\text { al-Masā'il }\end{array}$ \\
\hline $\begin{array}{l}\text { Bāb al-aṣwāt (18 masāil }) \\
{\left[129-13^{2}\right]}\end{array}$ & $50 a-64 a$ & $177-236$ & $53 \mathrm{a}[105]-68 \mathrm{~b}[136]$ & $63 b(13 b)$ \\
\hline 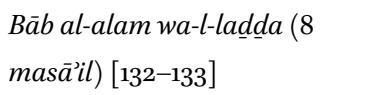 & $64 a-68 b$ & $163^{-176}$ & $48 \mathrm{a}[95]-53 \mathrm{a}[105]$ & $75^{a}(23 a)$ \\
\hline $\begin{array}{l}\text { Bāb al-ruțūba wa-l-yabūsa }(3 \\
\text { masāìl })\left[133^{-134}\right]\end{array}$ & $68 \mathrm{~b}-71 \mathrm{a}$ & $359-367$ & $\begin{array}{l}99 a[197]- \\
100 b[200]\end{array}$ & $81 \mathrm{~b}(27 \mathrm{~b})$ \\
\hline $\begin{array}{l}\text { Bāb al-akwān (25 masāìl) } \\
{\left[134-13^{6}\right]}\end{array}$ & $71 a-81 a$ & $237-288$ & $68 \mathrm{~b}[136]-83 \mathrm{~b}[166]$ & $83 b(29 a)$ \\
\hline $\begin{array}{l}\text { Bāb al-ta’lîf (11 masā'il) } \\
{[137-138]}\end{array}$ & $81 a-89 b$ & $289-307$ & $83 \mathrm{~b}[166]-89 \mathrm{~b}[178]$ & $99 \mathrm{~b}(40 \mathrm{~b})$ \\
\hline $\begin{array}{l}\text { Bāb al-i'timād (18 masāìl) } \\
{\left[13^{8-140]}\right.}\end{array}$ & $89 b-100 a$ & $309-35^{8}$ & $89 b[178]-99 a[197]$ & $105^{b}(49 a)$ \\
\hline $\begin{array}{l}\text { Bāb al-ḥayāt (24 masāìl) } \\
{[141-144]}\end{array}$ & $100 a-110 b$ & $369-409$ & $\begin{array}{l}100 \mathrm{~b}[200]- \\
111 \mathrm{~b}[222]\end{array}$ & $115^{a}\left(55^{b}\right)$ \\
\hline $\begin{array}{l}\text { Bāb al-qudra (35 masāìl) } \\
{[144-149]}\end{array}$ & $111 b-135^{a}$ & $433-5^{21}$ & $\begin{array}{l}117 \mathrm{~b}[234]- \\
138 \mathrm{~b}[276]\end{array}$ & $133 \mathrm{~b}(67 \mathrm{a})$ \\
\hline $\begin{array}{l}\text { Bāb al-itiqād }(22+37 \text { masāill }) \\
{\left[15^{0-161]}\right.}\end{array}$ & $135^{a-178 a}$ & $579-662$ & $\begin{array}{l}150 a[299]- \\
169 b\left[33^{8}\right]\end{array}$ & $160 a(85 b)$ \\
\hline $\begin{array}{l}\text { Bāb al-nazar wa-l-hāṭir }(25 \\
\text { masā'il })[162-166]\end{array}$ & $178 a-193 a$ & $663-696$ & $\begin{array}{l}169 \mathrm{~b}[338]- \\
177 \mathrm{~b}[354]\end{array}$ & $201 b(114 b)$ \\
\hline $\begin{array}{l}\text { Bāb al-irāda wa-l-kirāha }(35 \\
\text { masā'il })[167-171]\end{array}$ & $193 a-210 a$ & $523-577$ & $\begin{array}{l}138 \mathrm{~b}[276]- \\
150 a[299]\end{array}$ & $217 \mathrm{~b}(126 \mathrm{a})$ \\
\hline $\begin{array}{l}\text { Bāb al-šahwa wa-l-nifār (10 } \\
\text { masā'il) }[171-173]\end{array}$ & $210 a-216 b$ & $411-432$ & $111 \mathrm{~b}[222]-117 \mathrm{~b}[234]$ & $230 b\left(135^{b}\right)$ \\
\hline
\end{tabular}


(cont.)

\begin{tabular}{|c|c|c|c|c|}
\hline K. Riyạ̣̄̂tat al-afhām & $\begin{array}{l}\text { K. Dāmig } \\
\text { al-awhāmm }\end{array}$ & Tad $\underline{\text { kira }}$ & Šarḥ al-Tad̄kira & $\begin{array}{l}\text { Šarh 'Uyūn } \\
\text { al-Masā'il }\end{array}$ \\
\hline $\begin{array}{l}\text { Bāb al-idrāok } k^{81}(25 \text { masāòil }) \\
{\left[173^{-177]}\right.}\end{array}$ & $216 b-232 b$ & $697-743$ & $\begin{array}{l}177 \mathrm{~b}[354]- \\
188 \mathrm{a}[375]\end{array}$ & $233 \mathrm{~b}(137 \mathrm{~b})$ \\
\hline $\begin{array}{l}\text { Bāb al-nadam (15 masāìl) } \\
{[178-180]}\end{array}$ & $232 b-237 a$ & & & $245 \mathrm{a}(146 \mathrm{a})$ \\
\hline $\begin{array}{l}\text { Bāb al-lațāa } f a(7 \text { masāìl }) \\
{[180-182]}\end{array}$ & $237 \mathrm{a}-242 \mathrm{~b}$ & & & $253 \mathrm{a}$ \\
\hline $\begin{array}{l}\text { Bāb masāil mutafarriqa (5 } \\
\text { masā'il) [182-183] }\end{array}$ & $242 b-243 b$ & & & $255^{\mathrm{a}}$ \\
\hline $\begin{array}{l}\text { Bāb fìmasāìl al-hnilāf } \\
\text { wa-l-wifāq }(7 \text { masā̄il }) \\
{\left[183^{-184]}\right.}\end{array}$ & $243 \mathrm{~b}-247 \mathrm{a}$ & & & $256 \mathrm{a}$ \\
\hline $\begin{array}{l}\text { Bāb al-ilal wa-sāìir } \\
\text { al-mu'ațirirāt (20 masā'il) } \\
{[184-187]}\end{array}$ & $247 \mathrm{a}-25^{2 b}$ & & & $259 a$ \\
\hline $\begin{array}{l}\text { Bāb al-ğidāl (8 masāìl) } \\
{[187-188]}\end{array}$ & $25^{2 b-255^{a}}$ & & & $264 \mathrm{~b}$ \\
\hline $\begin{array}{l}\text { Bāb al-ḥudūd (6 masāìl) } \\
\text { [188-189] }\end{array}$ & $255^{\mathrm{a}-}$ & & & $267 \mathrm{a}$ \\
\hline
\end{tabular}

1504.-(j) Mecca, Umm al-Qura University 13063-4 (= nos. 12241, 12468), 2 vols, date: Rağab 1049/Nov 1639.-(k) Mecca, Umm al-Qura University 12252,

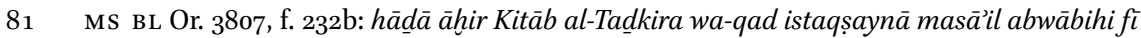
hādā l-Šarh al-mubārak, wa-qadzidnā 'alāl-abwāballatī ğama'ahā Ibn Mattawayh fì Tadkiratihi abwäban ăhar, fa-la-na'hud al-ānfi šarhihi. These additional topics are dependent on al-Ḥākim al-Ǧišumì’s Šarh ‘Uyūn al-masāill. 
2 vols, date: 838/1435 (possibly = (a)). - (l) Mecca, Umm al-Qura University 12140.- (m) Maktabat Āl al-Wazīr; cat. FMM Hु, p. 44 no. 71; date 823/1420.—(n) Maktabat 'Alī b. Ibrāhīm 63; al-ğuz' al-tāliț; cat. FMMḤ, p. 85 no. 164.-(o) Maktabat Muḥammad b. Yahyā b. 'Alī al-D̄ārī 1; cat. FMMḤ, p. 320 no. 767; date: 914/1508.-(p) Șan ‘̄à), Maktabat Muḥammad b. Muḥammad al-Kibsī; date: 1034/1625; cat. M TMHY, vol. 1, p. 223 no. 59/3.-(q) Hiğrat Falalla, Maktabat 'Abd al-Raḥmān Šāyim; microfilm; 3 vols; date: 1077/1666-1667; cat. м TM HuY, vol. 2, pp. 103-104 nos. 58-60.

\subsection{Reception History}

The most important testimonies for the reception history of Mirqāt al-anzār are the manuscripts listed above in section 2.1. Most of these manuscripts contain extensive marginal glosses. Additional information may be gleaned from the biographical literature. According to ṬZK, for instance, the following scholars are recorded to have studied K. Mirqāt al-anzāar: Șārim al-Dīn Ibrāhīm b. al-Qāsim b. al-Imām al-Mu’ayyad bi-llāh (d. 1152/1739-1740), the author of ṬZK; al-Ḥusayn b. al-Qāsim b. al-Imām al-Mu’ayyad bi-llāh Muhạmmad (d. 1131/1719), ṬZK, pp. 379-383 no. 221; Aḥmad b. Sa'd al-Dīn al-Miswarī (d. 1079/1668-1669), ȚZK, pp. 121-131 no. 48; Aḥmad b. Șāliḥ b. Abī l-Riğāl (d. 1029/1620), ṬZK, pp. 137147 no. 52; Aḥmad b. Ṣalāḥ al-Dawwārī (d. 1018/16og), ṬZK, pp. 148-151 no. 55; Aḥmad b. Muḥammad al-'Ayyānī (d. 1136/1724), ṬZK, pp. 189-19o no. 86; Sa'īd b. 'Ațāf al-Qidārī (d. 1023/1614), ṬZK, pp. 468-471 no. 271; Ṣālị̣ b. Aḥmad alSirāǧì (d. 1084/1673), ṬZK, pp. 493-496 no. 291; 'Abd Allāh b. al-Mahlā al-Nisā̄ī (d. 1028/1619), ṬZK, pp. 642-648 no. 387; 'Abd al-Hafìz b. al-Mahlā al-Nīsā̄ī (d. 1077/1666-1667), ṬZK, pp. 551-555 no. 328; 'Abd al-Wāsi' b. 'Abd al-Raḥmān al-Qurašì (d. 1108/1696-1697), ṬKK, pp. 577-58o no. 348; 'Abd Allāh b. Ahmad al-Wardasār (d. 975/1567-1568), ṬZK, p. 585 no. 355; 'Abd Allāh b. 'Alī al-Wazīr (d. 1147/1734-1735), ṬZK, pp. 620-624 no. 374; 'Alī b. 'Ațf Allāh al-Šāwarī (fl. 1oth/16th cent.), ṬZK, pp. 772-773 no. 477; 'Alī b. Muhammad b. Salāma (d. 109o/ 1679), ṬZK, pp. 785-787 no. 485 (sama'a Šarh al-Nağrī 'alā l-Qaläid 'alä l-Faqīh 'Abd Allāh b. Ahmad al-Harbī); 'Alī b. Muḥammad b. al-Mu’ayyad (d. 1120/1708), ŢZK, pp. 801-802 no. 502 (sama'a 'alä l-Sayyid Zayd b. Muhammad b. al-Hasan); al-Muhsin b. al-Mu’ayyad bi-llāh (d. 1141/1728-1729), ṬZK, pp. 888-89o no. 554; al-Imām al-Mu’ayyad bi-llāh Muḥammad b. al-Qāsim (d. 1054/1644), ṬZK, pp. 1049-1061 no. 664; Muḥammad b. Yaḥyā Bahrān (d. 957/1550), ṬZK, pp. 1103-1109 no. 694; al-Murtaḍā b. Qāsim al-Quțābarī (d. 931/1525), ṬZK, pp. 1117-1118 no. 700 (student of al-Nağrī); al-Hādī b. al-Wašlī (d. 1oth/16th cent.), ṬZK, pp. 1188-1189 no. 751; 'Abd al-Raḥmān b. 'Abd Allāh al-Ḥīmī (d. 1003/1595), ṬZK, pp. 556558 no. 331 ('alä l-faqüh Ahmmad b. Yahyā l-Ṣinānī); al-Ḥusayn b. al-Qāsim b. alMu’ayyad bi-llāh (d. 1131/1719); ṬZK, pp. 379-383 no. 221. 
Some important hawāš̄̌ on Mirqāt al-anzār have subsequently been transmitted as independent works:

1. al-Ḥasan b. Ahmmad al-Ğalāl (d. 1084/1673), al-Nukat al-farāid fi Šarh Muqaddimat al-Qalāid (= Hāšìya 'alā Šarh al-Qalā’id fì tașhịh al-'aqū’id, Šarh Šarh al-Qalāid or simply Šarh al-Ğaläl). ${ }^{82}$ These glosses, completed in 1046/1636, were frequently studied in the late 17 th and early 18 th centuries and are regularly quoted in the hawāšš of MS Munich Cod. arab. 1294 (see below).

2. al-Ḥasan b. Yahyā Sīlān al-Sufyānī al-Ṣa'dī (d. 1110/1699), Ta līqa 'alā Šarh al-Qaläid. ${ }^{83}$

3. al-Ḥasan(/al-Ḥusayn) b. Muhammad b. Saīid al-Mağribī (d. 1142/1729-1730), Hāšìa 'alā Šarh al-Qalāì. ${ }^{84}$

4. Hāšim b. Yahyāa al-Šāmī (d. 1158/1745) wrote superglosses on al-Ǧalāl's aforementioned Hāšiya. ${ }^{85}$ These superglosses also circulated as independent work entitled Șiyānat al-'aqā̉id bi-tağwìd al-nazar fi šarh al-Qalāì or Șiyā-

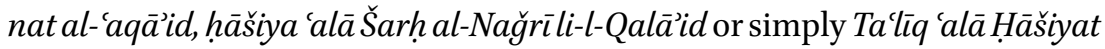
al-Ğaläl. This is the last substantial Zaydì ușūl al-dìn composition following the template of al-Murtaḍā's K. al-Qalā’id and al-Nağrì's Mirqāt al-anzāār which shaped Zaydī uṣūl al-dīn studies for more than three centuries. ${ }^{86}$ Beginning with the late 11 th $/ 1$ th century and until the late $13^{\text {th }} / 19$ th century, this tradition of usüulal-dìn was progressively marginalised. On the one hand, the dynasty of Qāsimī imāms gradually turned from a charismatic meritorious leadership into a hereditary dynasty devoid of scholarly aspiration and distinction. On the other hand the traditional Zaydī curriculum was thrown

82 Bт̣, pp. 225-227 no. 124; MTY, pp. 274-279; Schwarb, Handbook, no. 482; for manuscripts of al-Ǧalāl's Hāǎšiya see, for instance, $\operatorname{MJK}(\dot{\mathrm{G}})$ 597-6oo, 710, Mağmū' no. 3131, ff. 160-220; cat. 'İsawī, pp. 292-293; MFY, p. 149.

83 ṬZK, pp. 350-351 no. 204; BṬ, p. 249 no. 141; AMZ, p. $35^{6}$ no. 350; MFY, p. 153; MTY, pp. 286287 .

84 BṬ, pp. 269-270 no. 154; AMZ, pp. 346-347 no. 335; MFY, p. 156; al-Lağna al-cilmiyya fì Mu’assasat al-Imām al-Ṣādiq, Mư̌ğam al-turāt al-kalāmī, 5 vols, Qum 1423/2002 [hereafter мтк], vol. 3, p. 38 no. 4897; Aḥmad al-Ḥusaynī, Mu'allafāt al-Zaydiyya, 3 vols, Qum, Maktabat A. al-Mar'ašī al-Nağafì, 1413/1992 [hereafter MZ], vol. 1, p. 405 no. 1185; Schwarb, Handbook, no. 505 .

85 AMZ, pp. 1076-1077 no. 1155; M FY, pp. 156-157; Schwarb, Handbook, no. 509/1.

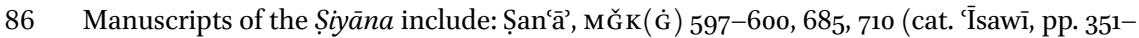
352); a microfilm of al-Šāmī's autograph-copy (MS MĞK( $\dot{\mathrm{G}}) 600$ ) is found in Maktabat Muhạmmad 'Abd al-'Aẓīm al-Hādī 166 (мтмHy, vol. 1, p. 478); MS BL Or. 4027 (= Glaser 349), ff. 1-186b, likely contains the Șiyāna (see $M T Y$, p. 217 no. 411). 
into disarray by al-Šawkānīs (d. 1250/1834) comprehensive reform project. ${ }^{87}$ Attempts to restore this tradition to its former glory over the course of the 2oth century resemble desperate efforts to reconstitute a lost treasure. ${ }^{88}$

As an exception that proves the rule, we may consider:

5. 'Abd al-Wahhāb b. Șalāḥ b. 'Alī al-Kastabān (d. after 1248/1832-1833),, Itḥāf al-nazzār bi-l-kašf 'an asrār Mirqāat al-anzār al-muntaza' min Ġāyāt al-afkār al-kāšif li-ma'ānì muqaddimat al-Baḥr al-zahhhār fi tawhìd dāat al-'aziz alqahhār al-hākkim bi-'adlihi 'alā kulli mutakabbir ğabbār. ${ }^{90}$

\subsection{MS Munich, Bavarian State Library, Cod. arab. $1294^{91}$}

According to the colophon (f. 111a), the manuscript was copied by Šaraf al-Dīn b. 'Abd al-Raḥmān Muḥammad b. Ğaḥhāf with the financial support and under

87 See Haykel, Revival and Reform, p. ix, 25-75 (36f.); idem, "Reforming Islam by Dissolving the Madhāhib: Shawkānī and his Zaydī Detractors in Yemen”, in Studies in Islamic Legal Theory, ed. B.G. Weiss, Leiden, Brill, 2002, p. 339: "[T] he eighteenth-century Imāms (of the Qāsimī dynasty) [...] progressively distanced themselves from Hādawī teachings and promoted and patronized Sunnī Traditionist scholars. Some of the reasons for the shift in madhhab orientation (never formally declared however) are the following: accommodating the sentiments of a large number of Sunnī Šãfi'i subjects in the tax-generating areas of Lower Yemen; legitimizing the dynastic ambitions of the eighteenth-century Qāsimī Imāms who did not live up to the ideal posited in Zaydī political doctrine; and deligitimizing Zaydism, in particular its political doctrine advocating the rejection of oppressive rule in the form of armed rebellion (hurūğ) or migration (hiğra)". I am not aware of any copy of Mirqāt al-anzār between 1172/1759 and 1316/1898 (then again 1345/1926). On this hiatus of more than a century in Zaydī-Hādawī scholarship see Schwarb, "Mu'tazilism in a 2oth century Zaydī Qur’ān commentary", p. 396, 402.

88 Among many other desperate attempts to safeguard this lost tradition and to restore its former strength one may mention Muhammad b. Yahyā b. Aḥmad b. Muhsin Mudācis al-Ṣan‘ānìs (d. 1351/1932-1933) K. al-Kāšif al-amīn 'an ğawāhir al-Tqd al-țamīn or 'Alī b. Muḥammad al-'Ağrì's Miftāh al-sa'āda. See my “Mu'tazilism in a 2oth century Zaydī Qur’ān commentary".

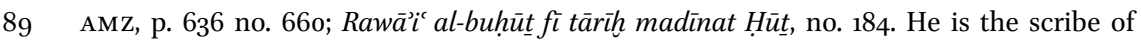
numerous extant Zaydī manuscripts.

$90 \quad$ MS Șa'da, Maktabat Ğāmi` al-Imām al-Hādī, Mağmū' no. 209; 128 ff.; autograph copy written between 1235/1819-1820 and 1239/1823-1824, i.e. during the lifetime of Muhammad $b$. 'Alī l-Šawkānī (d. 1250/1834); cat. M M MHY, vol. 2, p. 499; IZbACF CD no. 36o/2; Mecca, Umm al-Qura University 12102-12.

91 A brief description of the manuscript is found in Sobieroj, Arabische Handschriften, pp. $445-446$ no. 234 . 
the supervision of Abū Muḥammad Zayd b. Muḥammad b. al-Ḥasan b. al-Imām al-Manșūr bi-llāh al-Qāsim (d. 1123/1711), a great-grandson of Imām al-Manșūr (d. 1029/1620) and a nephew of Imām al-Mahdī Aḥmad b. al-Ḥasan b. al-Qāsim (d. 1092/1681).92 The copy was completed on 16 Rabī II 1108 (12 November 1696).

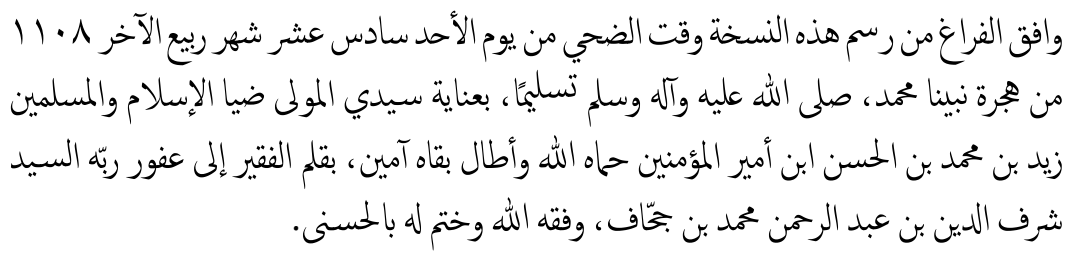

A number of prominent Zaydī scholars are mentioned to have studied Mirqāt al-anzār with Zayd b. Muhammad: 1) 'Alī b. Muhammad b. al-Mu'ayyad (d. 1120/ 1708; ṬZK, pp. 801-802 no. 502); 2) Muḥammad b. al-Qāsim Luqmān (d. 1133/ 1721); 3) Hāšim b. Yahyāa al-Šāmī (d. 1158/1745), the afore-mentioned author of Șiyānat al-'aqūìd bi-tağwìd al-nazar fi šarh al-Qalāidi; 4) Aḥmad b. 'Abd al-Raḥmān al-Šāmī (d. 1172/1759; вт̣, pp. 105-106 no. 43); 5) Muḥammad b. Ismāîl al-Amīr (d. 1182/1769).

\subsection{Works Quoted in the Margins of Ms Munich, Bavarian State Library, Cod. arab. 1294}

Almost all manuscripts of Mirqāt al-anzār contain marginal notes, but MS Munich Cod. arab. 1294 appears to be the most lavishly annotated among them. Even though the margins of other manuscripts contain quotations from works not cited in the margins of the Munich manuscript, ${ }^{93}$ the latter may serve as a reliable guide to the hitherto unexplored landscape of Zaydī kalāmstudies during the Ṭāhirid and early Qāsimī periods. Indeed, the hawāš̌̀ of each manuscript reveal a particular network of reference texts which constitute the

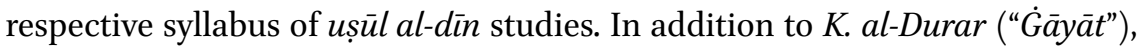
one or two other Zaydì uṣül al-dìn treatises are usually used as basic reference works. In ms Berlin, State Library, Landberg 883 this is Ibn Ḥanaš’s K. al-Gìyāṣa,

92 ȚZK, pp. 456-458 no. 264; вṬ, pp. 293-296 no. 176; AMZ, pp. 447-449 no. 436; MFY, p. 155 , 349, 395. Another manuscript, dated 1111/1699-1700, written bi-ināyat Zayd b. Muhammad b. al-Ḥasan is mentioned in MTMHY, vol. 2, p. 345 no. 121/3 (Šarh 'alā Muhtașar al-Sayyid Muhammad b. Ibrāhìm al-Wazīr wa-mustadrakuhu 'alā Nuhbat al-fikr).

93 See, among many other examples, Ms Berlin, State Library, Landberg 883: Šarh mafätīh

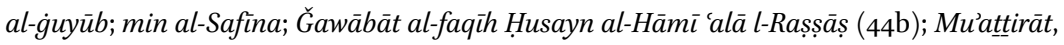
Šarh al-Mu'attirāat (79a); Mustasfā li-l-Ġazālī (83b), etc. 
in Ms Berlin Glaser 201/1 al-Qurašì's Minhāğ, in MS BL Or. 6266/4 'Izz al-Dīn's Mírāğ, etc.

The vast majority of the marginal notes in Ms Munich Cod. arab. 1294 are numbered and labeled. The specific arrangement and the geometry of the hawāšš in this manuscript follows Iranian and/or Ottoman models. Their precise origin will have to be determined in future studies. ${ }^{94}$

Besides quotations from and paraphrases of specific works, we find references to teaching sessions $\left(s a m \overline{\boldsymbol{a}}^{c}\right)$ [e.g. $1 \mathrm{~b}, 2 \mathrm{a}, 17 \mathrm{~b}, 45 \mathrm{a}, 5 \mathrm{~b}\left(s a m \bar{a}^{\mathrm{c}}\right.$... 'Abd al$H \bar{a} d \bar{\imath})$, dictation $\left(\boldsymbol{i m l} \overline{\boldsymbol{a}}^{\prime}\right)$ [e.g. 16a, 33b (with reference to al-Ḥākim al-Ğišumì's Šarh al- 'uyūn), 42b (min imlä' Sayyidinā 'Abd al-Hādī), and notes by the scribe (li-l-Kätib) [82a, 83b]..$^{95}$ The scribe regularly distinguishes between quotations

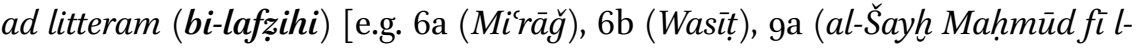
Fä̀iq), 18b] and quotations ad sensum (bi-ma'nāhi and $\left.\boldsymbol{m a}^{\mathbf{c}} \boldsymbol{n}^{\boldsymbol{a n}}\right)$ [e.g. 6a (Šarh al-Ușül), 18b, 47a $\left.\left(\dot{G} \bar{a} y \bar{a} t m a^{c} n^{a n}\right)\right]$. On some pages we find additional notes in a later hand (e.g. 10a, 62a*).

The following list of works quoted in the margins of Ms Munich Cod. arab. 1294 is arranged in chronological order.

\subsubsection{Works by Zaydī Authors}

1. Mașābịh li-Abī l-Abbās [105a, 105b]: Abū l-'Abbās Aḥmad b. Ibrāhīm alḤasanī (d. 353/964; AMZ, pp. 78-79 no. 42), K. al-Mașābīh fìl-sïra (мTмHY, vol. 1, p. 543 no. 514/2; ed. 'Ammān, Mu’assasat al-Imām Zayd ibn 'Alī alTaqāfiyya, 2002).

2. Ziyādāt [65b]: al-Imām al-Mu’ayyad bi-llāh Abū l-Ḥusayn Ạ̣mad b. alḤusayn al-Buṭhānī (d. 411/1020; EncIr, vol. 1, p. 884; AMZ, pp. 100-103 no. 72), K. al-Ziyāāāt; influential collection of responsa and fatwās.

3. Šarḥ (al-)Ușūl (li-l-Sayyid Aḥmad b. al-Ḥusayn) and Šarḥ al-Sayyid (lil-ușūl) [1b, 2a, 3b, 4a, 6a, 8a, 11a, 11b, 12b, 13a, 13b, 14b, 15a, 15b, 20a, 25a, 25b, 27a, 28b, 29b, 31b, 37a, 41a, 41b, 42a, 46b, 47a, 47b, 53a, 54b, 59a, 63a, 63b, 64a, 64b, 65a, 65b, 66a, 66b, 67b, 69b, 79a, 79b, 82b, 83a, 84b, 86a*, 92b, 107b, 110b]: al-Sayyid Mānkdīm (Šešdīv) (al-Imām al-Mustaẓhir billāh) Abū l-Ḥusayn Aḥmad b. Abī l-Ḥusayn al-Qazwīnī (d. ca. 425/1034; AMZ, p. 104 no. 74), [Ta'līq 'alā] Šarḥ al-Ușūl al-hamsa (GAS, vol. 1, p. 562 no. 27; Schwarb, Handbook, no. 318/1).

\footnotetext{
94 My colleague Hassan Ansari suggested to me that the layout, arrangement and annotation of the hawāšı̆ may point to a specific Iranian influence.

95 “Abd al-Hād̄̄” refers to 'Abd al-Hādī b. Aḥmad b. Ṣalāḥ 'al-Ḥasūsa' (d. 1048/1638); see below no. 34 .
} 


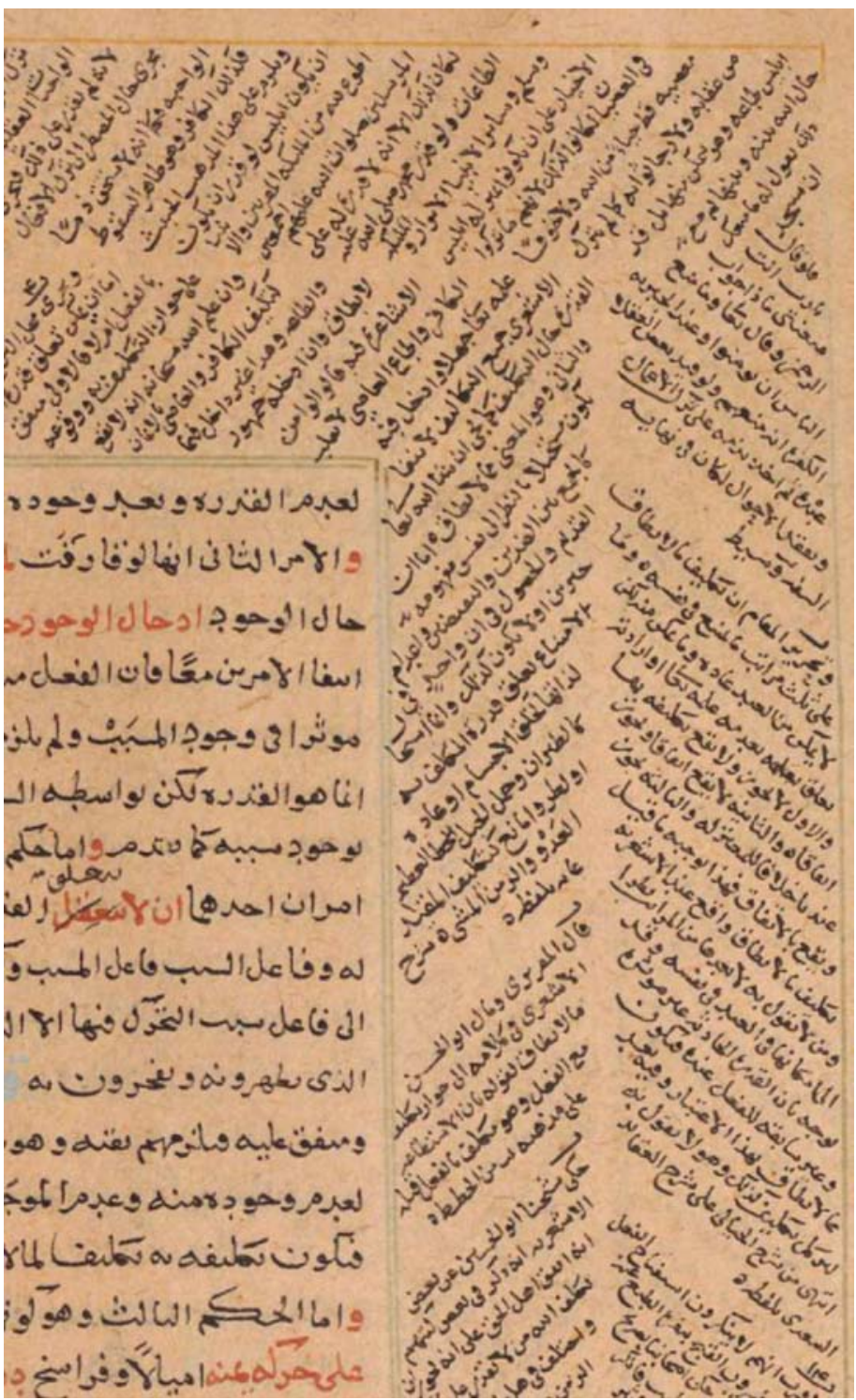

FIGURE 6.2 Ms Munich, Bavarian State Library, Cod. Arab. 1294, f. $37^{v}$ (extract) 
4. al-Šayh al-Murtaḍā 'Alīb.al-Husayn b. Mūsā, [...] wa-huwa șinwal-Šarīf al-Raḍi [16b]: al-Šarīf al-Murtaḍā 'Alam al-Hudā Abū l-Qāsim 'Alī b. alḤusayn b. Mūsā (d. 436/1044).

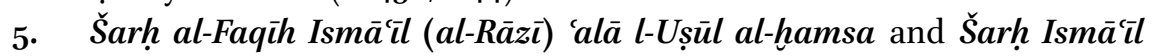
al-Rāzì li-(l)-Ușūl al-hamsa (li-l-Qāệ̀ Abd al-Ğabbār al-Mu'tazilī) and

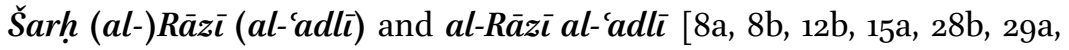
3oa, 55b, 56a, 67b, 70a, 97a]: Abū Muḥammad Ismāīl b. 'Alī al-Farrazādīi (fl. late $5^{\text {th }} / 1$ th and early 6th/12th centuries; ṬK K, p. 252 no. 134), Šarh alUșül al-hamsa (Schwarb, Handbook, no. 333/1); commentary on Mānkdīm Šešdīis's Talīq (see above no. 3).

6. Šams al-ulūm [48a]: Našwān b. Saīd b. Našwān al-Ḥimyarī (d. 573/1178; ȚZK, pp. 1173-1174 no. 745; AMZ, pp. 1060-1064 no. 1144), K. Šams al-'ulüm wa-dawǟ kalām al-Arab min al-kulüm (GAL, vol. 1, p. 301; GALS, vol. 1, p. $5^{28)}$.

7. Tadkira: Šams al-Dīn Abū l-Ḥasan Aḥmad b. al-Ḥasan b. Muhammad al-Rașsāṣ (d. 621/1224; ṬZK, p. 109 no. 37), K. al-Tadkira li-fawāid al-Tahṣill fil-tawhïd wa-l-ta'dïl (Schwarb, Handbook, no. 364/6); commentary on his father's (Ḥusām al-Dīn al-Ḥasan b. Muḥammad al-Rașṣāș, d. 584/1188) $K$. al-Tahṣil fì l-tawhìd wa-l-ta'dïl (Schwarb, Handbook, no. 357/3).

8. al-Wasît and Wasịt lil-faqīh Humayd [2a, 2b, 3a, 3b, 4b, 5a, 6a, 6b, 7a, $7 \mathrm{~b}$, 8a, 9a, 9b, 13a, 15a, 15b, 18b, 25b, 32a, 32b', 34a, 37a, 37b, 39a, 39b, 40b, 41a, 42b, 51a, 54a, 65a, 65b, 66b, 69a, 79a]: Ḥusām al-Dīn Abū 'Abd Allāh Ḥumayd b. Ahmad b. Muhammad al-Muhallī (d. 652/1254; ṬZK, pp. 421424 no. 247; AMZ, pp. 407-410 no. 408), al-Wasịt al-mufíd al-ǧàmi bayna l-Ị̇āh wa-l-Tqdal-farìd (Schwarb, Handbook, no. 374/2); autocommentary

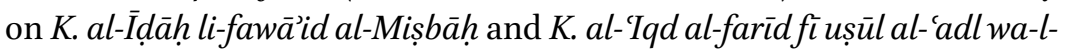
tawhìd.

9. al-Tasfiya [82b]:Muhammad b. al-Ḥasan al-Daylamī (d. 711/1311; M B, vol. 4, pp. 258-26o no. 1138; AMZ, pp. 883-884 no. 947), K. al-Tasfiya 'an almawāni al-muhlika al-murdiya.

10. Šarḥ alä l-Hulāṣa and Šarh Hulāṣa and Šarḥ al-Hulāṣa li-l-Faqīh Muhammad b. Yaḥyā Hanaš and Ġiyāṣa [3a, 3b, 4a, 6b, 13a, 14a]: Abū 'Abd Allāh Muḥammad b. Yaḥyā b. Aḥmad Ḥanaš (d. 719/1319; ṬZK, pp. 10981103 no. 692; AMZ, pp. 1008-1009 no. 1081), K. al-Anwār al-muta'alliqa alsātíia fì tahlīs fawāìd al-Hulāṣa al-nāfía (= K. Yāqūtat al-Ġiyāṣa al-ğāmi'a li-ma'ānī l-Hulāṣa, K. al-G̈iyāṣa fì šarh al-Hulāṣa) (Schwarb, Handbook, no. 398/1); commentary on Ahmad b. al-Ḥasan al-Rașșāṣ (d. 621/1224), K. al-Hulāșa al-nāfía bi-l-adilla al-qāțía fí fawā̄id al-Tābía (MFY, p. 118; Schwarb, Handbook, no. 364/3) which in turn is based on Qāḍi Ğa'far b. 
Aḥmad al-Buhlūlī (d. 573/1177-1178), K. al-Tābica bi-l-adillati l-qāțía (Schwarb, Handbook, no. 355/4). ${ }^{96}$

11. $\dot{G} u r a r$ and $\dot{G} u r a r$ wa-huğūl [4b, 12b, 13a, 27a, 28a, 29b, 31b, 32a, 34a, 4ob, 47a, 48a, 52b, 7ob, 71a, 85a]: al-Qāsim b. Aḥmad b. Humayd b. Aḥmad al-Muhallī (also known as 'Rāzì al-Zaydiyya', 1st half of 8th/14th cent.; grandson of Ḥusām al-Dīn al-Muhallì (above no. 8); ṬZK, pp. 855-856 no. 538.; AMZ, pp. 765-766 no. 823), K. al-Ġurar wa-l-huğūl fı kašf asrār al-ușūl (= K. al-G̈urarwa-l-huğūlfí bayān fawā’id Šarh al-uṣül) (M FY, p. 131; Schwarb, Handbook, no. 400/2); superglosses on Mānkdīm's Ta'līq 'alā Šarh al-Ușūl al-ḩamsa (see above no. 3).

12. Minhāğ and Minhāăg (al-)Quraš̌̀ and Qurašı̌ [1b, 2b, 4a, 5b, 7b, 8a, 11a, 12b, 14b, 16b, 18b, 19a, 19b, 25a, 27a, 27b, 28a, 28b, 29a, 29b, 31a, 35b, 36b, 4ob, 42a, 42b, 45b, 46a, 46b, 47a, 47b, 50b, 51a, 51b, 53a, 54b, 64b, 65a, 65b, 66a, 66b* , 67a, 67b, 68a, 7oa, 70b, 71a, 71b, 76b, 85b, 89a, 95b, 96a, 97a, 97b, 100a, 101a, 101b, 102a, 107b]: 'Imād al-Dīn Yahyyā b. al-Ḥasan al-Qurašīl-Șa'dī (d. 780/1378-1379; ṬZK, pp. 1215-1216 no. 772; ṬZṣ, vol. 2, pp. 16-20; AMZ, 1097-1098 no. 1176), K. Minhāğ al-tahqūq wa-mahạsin al-talfìq fìușūl al-dīn (= K. al-Minhāğ li-taqwìm al-i'wiğă $g$ = Minhāğ al-muttaqīn fìma'rifat rabb al-ālamin) (MFY, p. 129; Schwarb, Handbook, no. 411/1).

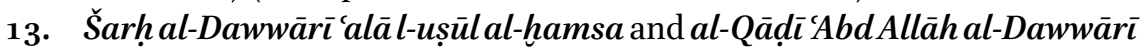
[8a, 11a, 12b, 31b]: Abū Muhammad 'Abd Allāh b. al-Ḥasan b. 'Ațîya l-Ṣa'dī al-Dawwārī (d. 80o/1397-1398; ṬZK, pp. 589-594 no. 361; AMZ, pp. 571573 no. 585), Šarh 'alā l-Ușūl al-hূamsa; superglosses on Mānkdīm Šešdīv's

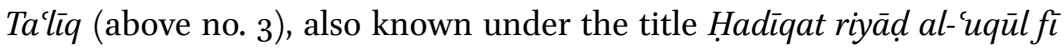
ta'līqat al-Qāḍ̄ al-Dawwwārī 'alā Šarh al-Ușūl. Dependent on al-Muhallī’s K. al-Gurar wa-l-huğūul (above no. 11).

14. Tálìq al-Hulāṣa [13b, 26a, 35b, 48b]: Abū Muhammad 'Abd Allāh b. alḤasan b. 'Ațīya l-Ṣa'dī al-Dawwārī (above no. 13), K. Ğawharat al-g̉awwāṣ wa-šarìdat al-qannās fi šarh Hulāșat al-Rașșạș; commentary on Aḥmad b. al-Hasan al-Rașșāṣ (d. 621/1224), K. al-Hulāṣa al-nāfía bi-l-adilla al-qāțía fì fawāid al-Tābía (MFY, p. 118; Schwarb, Handbook, no. 364/3) which in turn is based on Qāạī Ğafar b. Aḥmad al-Buhlūlì (d. 573/1177-1178), K. alTābica bi-l-adillati l-qāțía (Schwarb, Handbook, no. 355/4). Al-Dawwārì's Tali $q$ depends on the aforementioned commentary by Ibn Ḥanaš (see above no. 10).

96 There are several other commentaries on the Hulāṣa, but the above-listed quotations in the hawā̌š of Ms Munich Cod. arab. 1294, all refer to Ibn Ḥanašss commentary. See also al-Dawwārī’s Ta lìq al-Hulāṣa mentioned below. 
15. $\dot{\boldsymbol{G}} \overline{\boldsymbol{a}} \boldsymbol{y} \overline{\boldsymbol{a}} \boldsymbol{t}[\mathrm{ib}, 2 \mathrm{~b}, 3 \mathrm{a}, 3 \mathrm{~b}, 4 \mathrm{a}, 4 \mathrm{~b}, 5 \mathrm{a}, 5 \mathrm{~b}, 6 \mathrm{a}, 6 \mathrm{~b}, 7 \mathrm{a}, 7 \mathrm{~b}, 8 \mathrm{a}, 8 \mathrm{~b}, 9 \mathrm{a}, 9 \mathrm{~b}, 10 \mathrm{a}, 10 \mathrm{~b}$, $11 \mathrm{a}, 11 \mathrm{~b}, 12 \mathrm{a}, 12 \mathrm{~b}, 13 \mathrm{a}, 13 \mathrm{~b}, 14 \mathrm{a}, 14 \mathrm{~b}, 15 \mathrm{a}, 15 \mathrm{~b}, 16 \mathrm{a}, 16 \mathrm{~b}, 17 \mathrm{a}, 17 \mathrm{~b}, 18 \mathrm{a}, 18 \mathrm{~b}, 19 \mathrm{a}$, 19b, 20a, 20b, 21a, 21b, 22a, 22b, 23a, 23b, 24a, 24b, 25a, 25b, 26a, 27a, 27b, $28 \mathrm{a}, 28 \mathrm{~b}, 29 \mathrm{a}, 29 \mathrm{~b}, 30 \mathrm{a}, 30 \mathrm{~b}, 31 \mathrm{a}, 31 \mathrm{~b}, 32 \mathrm{a}, 32 \mathrm{~b}, 33 \mathrm{a}, 33 \mathrm{~b}, 34 \mathrm{a}, 34 \mathrm{~b}, 35^{\mathrm{a}}, 35^{\mathrm{b}}$, $36 a, 36 b, 37 a, 37 b, 38 a, 38 b, 39 a, 39 b, 40 a, 40 b, 41 a, 41 b, 42 a, 42 b, 43 a, 43 b$, 44a, 44b, 45a, 45b, 46a, 46b, 47a, 47b, 48a, 48b, 49a, 49b, 50a, 50b, 51a, 51b, $5^{2 a}, 5^{2 b}, 53 a, 53 \mathrm{~b}, 54 \mathrm{a}, 54 \mathrm{~b}, 55^{\mathrm{a}}, 55^{\mathrm{b}}, 56 \mathrm{a}, 56 \mathrm{~b}, 57 \mathrm{a}, 57 \mathrm{~b}, 58 \mathrm{a}, 58 \mathrm{~b}, 59 \mathrm{a}, 59 \mathrm{~b}$, 6oa, 6ob, 61a, 61b, 62a, 62b, 63a, 63b, 64a, 64b, 65a, 65b, 66a, 66b, 67a, 67b, 68a, 68b, 69a, 69b, 70a, 70b, 71a, 71b, 72a, 72b, 73a, 73b, 74a, 74b, 75a, 75b, $76 \mathrm{a}, 76 \mathrm{~b}, 77 \mathrm{a}, 77 \mathrm{~b}, 78 \mathrm{a}, 78 \mathrm{~b}, 79 \mathrm{a}, 79 \mathrm{~b}, 80 \mathrm{a}, 80 \mathrm{~b}, 81 \mathrm{a}, 81 \mathrm{~b}, 82 \mathrm{a}, 82 \mathrm{~b}, 83 \mathrm{a}, 83 \mathrm{~b}$, $84 a, 84 b, 85 a, 85 b, 86 a, 86 b, 87 a, 87 b, 88 b, 89 a, 89 b, 91 a, 92 a, 93 b, 94 a$, 94b, 95a, 95b, 96a, 96b, 97a, 97b, 99a, 99b, 100b, 101a, 101b, 105b, 106a, 106b, 107a, 107b, 108a, 108b, 109a, 109b, 110a, 110b]: al-Mahdī li-Dīn Allāh Aḥmad b. Yahyyā l-Murtạ̣ā (d. 840/1436-1437), K. Ġāyāt al-afkār wa-nihāyat alanzāar al-muḥ̄ṭa bi-'ağàib al-Baḥr al-zahḩār (see above section 2.). Ġāyāt is here used as a totum pro parte referring to K. al-Durar al-farāid fi šarh K.

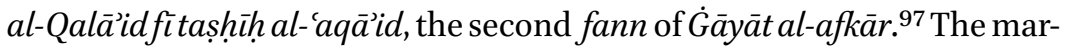
gins of Ms Munich Cod. arab. 1294 comprise more than 1.200 (!) quotations from $K$. al-Durar. The scribe indicates when a quotation from the $\dot{G} \bar{a} y \bar{a} t$ is not taken from the parallel chapter of $K$. al-Durar (al-Ġāyāt min $\dot{g} a y r i$ $h \bar{a} \underline{d} \bar{a} l$-mahall). Occasionally, there are unspecified references to Hāšiyat al-Gं̄àāt [e.g. 2ob].

16. Dāmig̀ and Šarḥ Riyāệt (al-afhām) and Riyāḍa wa-šarḥuhu [6a, 3oa, 35b, 39a, 76a (Riyāọa)]: al-Mahdī li-Dīn Allāh Aḥmad b. Yahyā l-Murtaḍā (d. 840/1436-1437), K. Dāmig̉ al-awhām fi šarh Riyāột al-afhām fì lațīf al-kalām (see above 2.2.1.). Occasionally, the margins also refer to unspecified Hāšìat Riyāọa [e.g. 39a].

17. Šarḥ al-Milal li-l-Imām al-Mahdī and Šarḥ al-Milal wa-l-Niḥal [16b, 17a, 82b]: al-Mahdī li-Dīn Allāh Aḥmad b. Yahyyā l-Murtạ̣ā (d. 840/1436-1437), K. al-Munya wa-l-amal fi šarh K. al-Milal wa-l-niḥal (see above n. 56).

18. Šarḥ Nukat li-l-Imām al-Mahdī and Šarh Nukat al-farāidd [5ob, 51a]: alMahdī li-Dīn Allāh Aḥmad b. Yaḥyā l-Murtaḍā (d. 840/1436-1437), Ǵurar al-fawā’id fi šarh Nukat al-farā’id; autocommentary on Nukat al-farā'id fi ma'rifat al-Malik (/al-Hayy) al-wāḥid.

19. $\dot{G}$ ayt [109a, 11ob]: al-Mahdī li-Dīn Allāh Aḥmad b. Yahyā l-Murtaḍā (d. 840/1436-1437), K. al-Ġayt al-midrār al-mufattị̣ li-kamā̇im al-Azhār; autocommentary on $K$. al-Azhār.

97 The use of ' $\dot{G} \bar{a} y \bar{a} t$ ' to refer to $K$. al-Durar is also attested in the biographical literature (see e.g. ȚZK, p. 786 no. 485$)$. 
20. İtār al-ḥaqq 'alä l-halq [4ob]: 'Izz al-Dīn Abū 'Abd Allāh Muhammad b. Ibrāhīm b. 'Alī al-Wazīr (d. 840/1436-1437; ṬZK, pp. 896-902 no. 556; AMz, pp. 825-831 no. 880), K. İtār al-haqq 'alā l-halq fì radd al-hiläfät ilā l-haqq min ușül al-tawhìd. The quotation is said to be taken min hațt Sayyidì Salāḥ b. Ahmad b. 'Abd Allāh b. al-Wazìr (d. 1044-1048/1634-1639), a great-grandson of Ibn al-Wazīr.

21. al-Mag̉ram [2b]: Yahyyā b. Aḥmad b. 'Alī Mag̉ram (d. 865/1461; ṬzK, pp. 1206-1207 no. 765; AMZ, pp. 1089-109o no. 1165), Šarh al-Baḥr al-zahhār.

22. Bayān [41a]: 'Imād al-Dīn Yahyāā b. Aḥmad b. 'Alī b. Muẓaffar (d. 875/1470; TZZK, pp. 1205-1206 no. 764;A MZ, pp.1092-1093 no. 1168), K. al-Bayān al-šăfi al-muntaza' min al-Burhān al-kāfí (MFY, p. 225); extracts from al-Burhān al-käfi by Muḥammad b. Ḥamza b. Muẓaffar (d. 796/1394; AMZ, pp. 895897 no. 963 ; мTK, vol. 2, p. 59 no. 2765 ; MZ, vol. 1, p. 205 no. 557) with an introduction on the ușülān. (see above n. 42)

23. Nağrī [69a]: unspecified.

24. Huâlidī [99a]: Šams al-Dīn Aḥmad b. Muḥammad al-Ȟālidī (d. 880/1475; T?ZK, pp. 203-204 no. 96; AMZ, pp. 166-167 no. 153; see above n. 41), unspecified work.

25. Bukurī 'alā l-Minhāğ and Šarḥ al-Minhāğ li-l-Bukurī and Bukurī and al-Kawkab al-wahhāğ [1b, 3a, 12a, 14a, 14b, 16b, 22a, 26a, 29b, 36a, 4ob, 42a, 45b, 50a, 59a, 65b, 66a, 70a*, 76b, 92b, 96a]: 'Alī b. Muḥammad b. Ahmad al-Bukurī (d. 882/1478; see above n. 40), K. al-Kawkab al-wahhāğfi kašfasrār al-Minhā̄̆ (= al-Kawkab al-wahhāğ fi šarh al-Minhā $\breve{g}=$ = al-Sirāğ al-wahhāğfı šarḥ al-Minhā mentary on al-Qurašî's (d. 780/1378-1379) K. al-Minhāğ (see above no. 12).

26. Šarh (al-Bukurì li-)Muqaddimat al-Bayān and Šarh al-Bukurī [1b, 13a, 46b, 69a]: 'Alī b. Muḥammad b. Aḥmad al-Bukurī (d. 882/1478; see above n. 40), Šarh Muqaddimat al-Bayān (see above no. 22); commentary (coauthored with 'Abd Allāh b. Muhammad al-Nağrī) on the Muqaddima of K. al-Bayān al-šāfí al-muntaza' min al-Burhān al-kāfı́ by 'Imād al-Dīn Yahyā b. Aḥmad b. 'Alī b. Muẓaffar (d. 875/1470; ṬZK, pp. 1205-1206 no. 764; AMZ, pp. 1092-1093 no. 1168; see above n. 43). ${ }^{98}$

27. al-Mi'rä̆ğ and Izz al-Dīn [1b, 2b, 3a, 3b, 4a, 4b, 5b, 6a, 6b, 9a, 9b, 10a, 10b, 11b, 13a, 13b, 14b, 15a, 15b, 16a, 20b, 23b, 24a, 25a, 27a, 27b, 28a, 28b, 29a, 29b, 31b, 32a, 33a, 34b, 36b, 40a, 41a, 41b, 42b, 44a, 46b, 47a, 47b, 48a, 5ob, 54a, 54b, 56a, 58a, 59a, 59b, 62a, 62b, 63a, 63b, 64b, 65b, 66a, 66b, 67a, 67b,

98 Šarh al-Bukurī is ambiguous and may refer to either Šarḥ Minhāğ al-Qurašı̃ or Šarh Muqaddimat al-Bayān. 
69a, 7ob, 71a, 71b, 78b*, 79a, 79b, 80a, 85a, 86a*, 87b, 88a, 88b, 89b, 9ob, 96a, 96b, 97a, 97b, 98a, 98b, 100a, 100b, 104a, 107b, 11ob]: al-Imām al-Hādī li-Dīn Allāh 'Izz al-Dīn b. al-Ḥasan b. 'Alī b. al-Mu’ayyad (d. 90o/14941495; тৃZK, pp. 670-673 no. 397; AMZ, pp. 641-645 no. 668), K. al-Mi'rāă fi Šarḥ al-Minhāăg (= K. al-Mírāă ilā kašf (/istihrāăğ) asrār al-Minhāğ almuqawwima li-l-i'wiğāăg = Šarh Minhāğ al-Quraš̄ ) (MFY, p. 680; Schwarb, Handbook, no. 443/1); commentary on al-Qurašî's (d. 780/1378-1379) K. alMinhāğ (see above no. 12).

28. Šarḥ Fatḥ [99b]: Yahyyā b. Muḥammad al-Miqrāì al-Hāritīi al-Maḍhağī (d. 980/1572; ṬZ, pp. 1256-126o no. 796; AMZ, pp. 1147-1159 no. 1211), $K$. al-Šamūs wa-l-aqmār fì šarh Fath al-ġaffār li-muqfalāt al-ațāār.

29. min hațt al-Hīmī [15b]: 'Abd al-Raḥmān b. 'Abd Allāh al-Ḥimì (d. 1003/ 1595; ṬZK, pp. 556-558 no. 331); possibly hawā̌š in the handwriting of al-Hīmī on Mirqāt al-anzār ${ }^{99}$

3o. al-Asāe [53b]: al-Imām al-Manșūr bi-llāh al-Qāsim b. Muḥammad b. 'Alī (d. 1029/1620; ṬZ, pp. $860-869$ no. 543; AMZ, pp. $777-782$ no. 839; M FY, pp. 610-617), K. al-Asās li-tașḥ̣̂h 'aqā̉id al-akyās fì márifat rabb al'ālamìn wa-'adlihi 'alā l-mahlūqìn = al-Asās al-mutakaffil bi-kašfal-iltibās (Schwarb, Handbook, no. 462/1).

31. Šarḥal-Asās [83b, 93b]: refers to one of the following Šurūḥ on K. al-Asās: Aḥmad b. Muḥammad b. Șalāḥ al-Šarafĩ (d. 1055/1646; т̣ZK, pp. 179-182 no. 81; MB, vol. 1, pp. 441-445 no. 216; AMZ, pp. 171-173 no. 158), Sifǟs șudūr al-nās bi-šarh ma änīl-Asās (= Šarh al-Asās al-kabīr) (Schwarb, Handbook, no. 471/2); 'Uddatal-akyās al-muntaza'min Šifā’șudūral-nāsfišsarḥma'ānī l-Asās (= Šarh al-Asās al-șaḡir) (Schwarb, Handbook, no. 471/1); Šams alDīn Aḥmad b. Muḥammad b. Luqmān (d. 1039/1629-1630; ṬZK, pp.183-185 no. 82; м B, vol. 1, pp. 433-437 no. 214), Kašf al-ilbās 'an qawā'id al-Asās (Schwarb, Handbook, no. 465/1).

32. Šarh al-Gìyāt [20a]: probably refers to Bahāe al-Dīn Luṭ̂ Allāh b. Muhammad al-Ġiyāt al-Zafî̀ī (d. 1035/1625-1626; AMz, pp. 796-798 no. 853), K. al-Manāhil al-șāfiya fì šarh /kašfma'ānīal-Šäfiya (or, less likely, to his Šarh al-fușūl al-lu'lu'iyya or Šarh huṭ̂tbat/muqaddimat al-Asās).

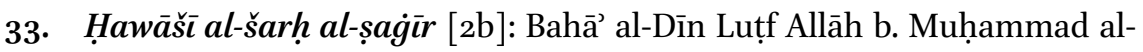
Giyāt al-Zạî̄ī (d. 1035/1625-1626), glosses on Aḥmad b. Muḥammad b. Șalāḥ al-Šarafì (d. 1055/1646), Uddat al-akyās al-muntaza'min Šifǟ șudūr

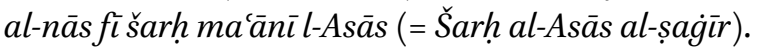

99 See ȚZK, pp. $55^{6-55^{8}}$ no. 331, where his studies of $K$. [al-Durar] al-farā̉id, K. Dāmig al-awhām and Šarh al-Qalāìd (= Mirqāt al-anz̄ār) are highlighted. 
34. qāla Sayyidunā 'Abd al-Hādì b. Aḷmad [6a]: 'Abd al-Hādī b. Aḥmad b. Șalāh 'al-Hasūsa' (d. 1048/1638; ṬZK, pp. 575-577 no. 347; MB, vol. 3, pp. 61-63 no. 754), according to ȚZK, p. 557 the foremost student of the aforementioned 'Abd al-Raḥmān b. 'Abd Allāh al-Hīmī (see above no. 29).

35. al-Badr al-sārī šarḥ wāsițat al-darārī li-l-Sayyid Muḥammad al-Muftī and Šarh al-Muftī and Badr sārī and Šarh al-Darārï ${ }^{100}$ [7a, 12b, 33a, 42b, 58a, 85b]: Badr al-Dīn Muḥammad b. 'Izz al-Dīn b. Muḥammad al-Muftī al-Mu'ayyadī (d. 1049/1639-1640; ŢZK, pp. 1021-1022 no. 643; AMZ, pp. 940942 no. 1016), K. al-Badr al-sārī (fì) šarḥ Wāsițat al-darārîfì tawhīd al-Bāri’ (Schwarb, Handbook, no. 469/1); autocommentary on his K. Wāsițat aldarārīfì tawhìd al-Bārì.

36. Šarḥuhu li-l-Takmila, [85b]: Badr al-Dīn Muhammad b. 'Izz al-Dīn b. Muḥammad al-Muftī al-Mu’ayyadī (d. 1049/1639-1640), Šarh Takmilat alaḥkām, a commentary on Aḥmad b. Yaḥyā l-Murtaḍā's K. al-Takmila lil-Ahkām wa-l-tasfiya min bawāțin al-ātām (see above section 2. for the structure of al-Bahr al-zahhār).

37. min haț al-Mufti [24a, 31b, 33a]: Badr al-Dīn Muhammad b. 'Izz al-Dīn b. Muhammad al-Muftī al-Mu’ayyadī (d. 1049/1639-1640), possibly from an autograph of his hawā̄̌š on Mirqāt al-anzāar.

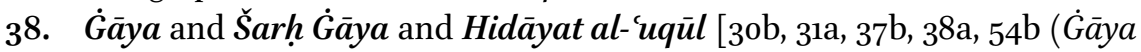

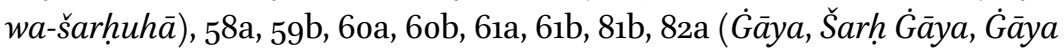
wa-šarḥuhā), 82b, 86b, 98b (intahā matn ${ }^{a n} w a-s ̌ a r h h^{a n}$ min Hidāyat al-'uqūl bilafžihi)]: Šaraf al-Dīn al-Ḥusayn b. al-Imām al-Qāsim b. Muḥammad (d. 1050/1640; TZKK, pp. 370-377 no. 220; MB, vol. 2, pp. 179-188 no. 482; AMZ, pp. 388-389 no. 386), K. Ġāyat al-su'l fì ílm al-usül (Schwarb, Handbook, no. 470/1) and autocommentary K. Hidāyat al-'uqūl ilā Ġāyat al-su'lfí 'ilm al-ușūl (= Šarh al-G̈āya) (Schwarb, Handbook, no. 470/2). Both texts are often mentioned together ( $\dot{G} \bar{a} y a w a-s ̌ a r h u h \bar{a})$.

39. mā nuqila min hatṭ Sayyidì al-Husayn b. al-Qāsim 'alā Šarḥ al-Asās: Šaraf al-Dīn al-Ḥusayn b. al-Imām al-Qāsim b. Muḥammad (d. 1050/1640; TZK, pp. 370-377 no. 220; MB, vol. 2, pp. 179-188 no. 482; AMZ, pp. 388-389 no. 386), autograph of his hawā̄̌̌̀ on Šarh al-Asās.

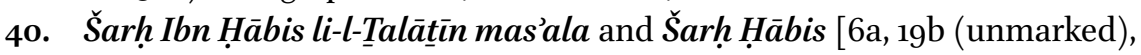
28a]: Aḥmad b. Yaḥyā b. Aḥmad (Ibn) Ḥābis al-Dawwārī al-Ṣa‘dī (d. 1061/ 1651; ṬZK, pp. 234-237 no. 117; AMZ, pp. 199-201 no. 193), K. al-Ị̇āh 'alā

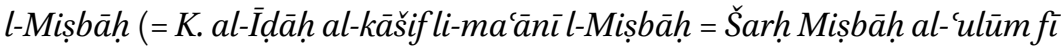
ma'rifat al-Hayy al-qayyūm = Šarh al-Miṣbāh $)$ (M TK, vol. 1, p. 548; Schwarb,

$100 \quad \breve{S} a r h ̣$ al-Darārū is easily confused with Šarh al-Dawwārī (above no. 13). 
Handbook, no. 473/2); commentary on Aḥmad b. al-Ḥasan b. Muḥammad al-Rașșāș’s (d. 621/1224) Miṣbāḥ al-ulūm fì ma'rifat al-Hayy al-qayyūm (= al-Talätūinal-mas'ala).

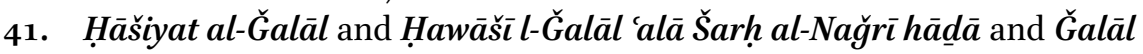
[1b, 15b, 20a, 21b, 22a, 22b, 23a, 23b, 30a, 30b, 31a, 50a, 50b, 61b, 62a, 63a, 72a, 92b]: al-Ḥasan b. Aḥmad al-Ğalāl (d. 1084/1673; ṬZK, pp. 287-29o no. 152; BṬ, pp. 225-227 no. 124; AMZ, pp. 299-303 no. 280), ${ }^{101}$ Hēäšiya 'alä Šarh al-Qalā’id;102 glosses on K. Mirqāt al-anzār (see above n. 82). ${ }^{103}$

42. Šarḥ al-Ğaläl [14a, 22a]: In some contexts it likely refers to Šarh al-Ğalāl 'alā l-Tahdīb (= Taqrīb Tahdīb al-manțiq).

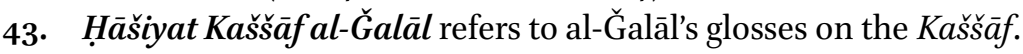

44. Häššyat al-Kaššăf and Hawāš̌ l-Kaššă $[20 \mathrm{a}, 33 \mathrm{~b}]$ : usually refers to alTaftāzānì's Hawāšl̆, but at times it may also refer to one of the numerous Zaydī glosses on the Kaššâff, e.g. by Ṣālih b. Dāūùd al-Ānisī (d. 110o/16881689) which in turn depend on Yahyā b. al-Q̨āsim b. 'Umar b. 'Alī al-'Ulwī

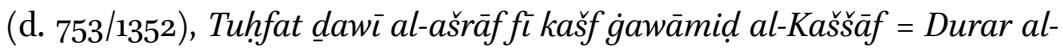
așdāffí hall 'uqad al-Kaššā $\bar{f}$ = Hāšiyat al-Alwī. ${ }^{104}$ Besides, there are also references to superglosses Ḥāšiyat 'alā hâāsiyat al-Kaššăf [21a].

45. Mağmū' al-Faqūh al-fậ̂il al-'āmil Șâliḥ al-Maqbalī [72a]: collection of writings by Ṣâliḥ b. Aḥmad b. Mahdī l-Maqbalī (d. 1108/1696; ṬZK, p. 502 no. 298; AMZ, pp. 491-493 no. 492).

46. min hațt al-Sayyid al-Allāma Șalāḥ b. Aḷmad al-Rāziḥ̂̉ [61b]: Șalāḥ b. Aḥmad al-Rāziḥi (d. after 1115/1703; ṬZK, pp. 519-520 no. 306), possibly from an autograph of his hawā̄š̀ on Mirqāt al-anzāar. In ṬZK p. 189 no. 86 al-Rāziḥi is mentioned as teacher of Šarh al-Muqaddima li-l-Nağrí.

47. naqaltuhu min hațt al-Qāộ̀ al-Allāma Aḷmad b. Șālị̣ b. Abì l-Riğāl [92b]: Šihāb al-Dīn Aḥmad b. Șāliḥ Ibn Abī l-Riğāl (d. 1092/1681; ṬZK, pp. 137-147 no. 52), the author of Mațla' al-budūr (see above n. 14).

101 On al-Ğalāl see also the editor's introduction to Nizām al-fușūl, i.e. al-Ğalāl's commentary al-Fușūl al-lu’lu’ìya ( fì ușūl al-figh), ed. Aḥmad 'Alī Nūr al-Dīn, Șan'ā', Markaz al-Turāt wal-Buhūț al-Yamanī, (available @ http://dc253.4shared.com/doc/ywD9NJVo/preview.html [consulted 30/11/2013]).

102 Al-Ǧalāl refers to it as Šarh Šarh al-Qalāid (e.g. Nizāam al-Fusūul, vol. 1, p. 14, 210, vol. 2, p. 1, $54-55)$.

103 At times (e.g. 62a) Šarh al-Ǧalāl may also refer to his hawā̄̌̌̌ on Zamahšarī’s Kaššăâf.

104 See Walid A. Saleh, "The Gloss as Intellectual History: The Häshiyahs on al-Kashshäf", Oriens 41 (2013), pp. 217-259, pp. 236-238 for Taftāzānī’s Hawā̌̌t. One should add here the rich tradition of glosses on the Kaššăf by Yemenite Zaydīs and Šāfičs. For some aspects of the early transmission of the Kaššăf in Yemen see http://ansari.kateban.com/entry2005 .html [consulted 08/04/2014]. 
1. al-Šayh Maḥmūd fì l-Fä̀iq and Ibn al-Malähimì and $\boldsymbol{a l - F a ̈ i q}$ [9a, gb, 37a, 37b, 38b, 39a, 41a, 55a, 66b, 67b]: Rukn al-Dīn Mạ̣mūd b. Muhammad al-Malāḥimī al-Huwārazmī (d. 536/1141), K. al-Fāiq fì uṣūl al-dīn.

2. qâla l-Šayh Mạ̣mūd and Mu'tamad [7a, 67b (actually from the Fã'iq)]: Rukn al-Dīn Mạ̣mūd b. Muḥammad al-Malāḥimī al-Ḩwārazmī (d. 536/ 1141), K. al-Mu'tamad fì ușūl al-dīn.

3. al-Kaššăf and Ğär Alläh [1b, 3b, 4b, 10b, 12b, 14b, 21a, 23b, 30a, 39a, 39b, 40a, 40b, 41a, 42a, 55b, 56a, 57b, 6oa, 61a, 62a, 62b, 63a, 65b, 66b, 67b, 68b, 69a, 70a, 72b, 73b, 74a, 76a, 77a, 79a, 8oa, 8ob, 81a, 82b, 83a, 83b, 84b, 85a, 94a, 96b, 97b, 100b, 106a, 107b]: Ǧār Allāh Abū l-Qāsim Mạ̣mūd b. 'Umar al-Hुwārazmī l-Zamahšarī (d. 538/1144), K. al-Kaššāf 'an haqā̄iq al-tanzīl wa-'uyūn al-aqāwìl fì wuğūb al-ta’wĭl (GAL, vol. 1, p. 290; GALS, vol. 1, p. 507). ${ }^{105}$

3.2.3 Works by non-Mu'tazilī Sunnī Authors

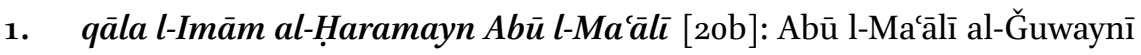
(d. 478/1085; $E I^{2}$, vol. 2, pp. 605-606), K. al-Iršād fì ușūl al-dìn.

2. Máālim al-tanzīl [38b, 39a]: Abū Muhammad al-Husayn b. Mas'ūd al-

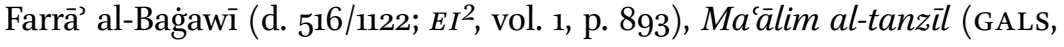
vol. 1, p. 592, 622); extracts from Aḥmad b. Muhammad al-Tálabī's (d. 427/ 1035) al-Kašfwa-l-bayān 'an tafsìr al-Qur'ān, very popular among Šāfi'īs in Yemen and elsewhere.

3. Muḥașṣal [29b]: Faḩr al-Dīn al-Rāzī (d. 6o6/1210), K. Muḥașșal afkār almutaqaddimin wa-l-muta'ahhirin min al-'ulamä'sa-l-hukamä'sa-l-mutakallimìn.

4. Šarḥ al-Muḥaṣṣal or Šarḥ al-Kātibī [29b (qāla Šārị̣ al-Muḥaṣṣal li-lRāzī [...] tammat Šarh al-Kātib̄̄)]: Nağm al-Dīn 'Alī b. 'Umar al-Dabīrān al-Kātibī al-Qazwīn̄̄ ("Šāriḥ al-Muḥașṣal li-l-Rāzī”) (d. 675/1277), K. alMufașșal fi šarh al-Muḥașșal (Ms Istanbul, Damad Ibrahim Pasha 821

105 The use of the Kaššăf in glosses to a work on uṣūl dīn (as is the case with Nağrī's Mirqāt al-anzāar sheds further light on the relevance of this commentary to theological issues, which has been doubted by some (A.J. Lane, "You can't tell a book by its author: A study of Mu'tazilite theology in al-Zamakhsharī's (d. 538/1144) Kashshäf", Bulletin of the School of Oriental and African Studies 75 (2012), pp. 47-86). For a more convincing alternative view see Kifayat Ullah, Al-Kashshāf: al-Zamakhsharı̈’s (d. 538/1144) Mu'tazilite exegesis of the Qur'ān, doctoral dissertation, Washington DC, 2013. 


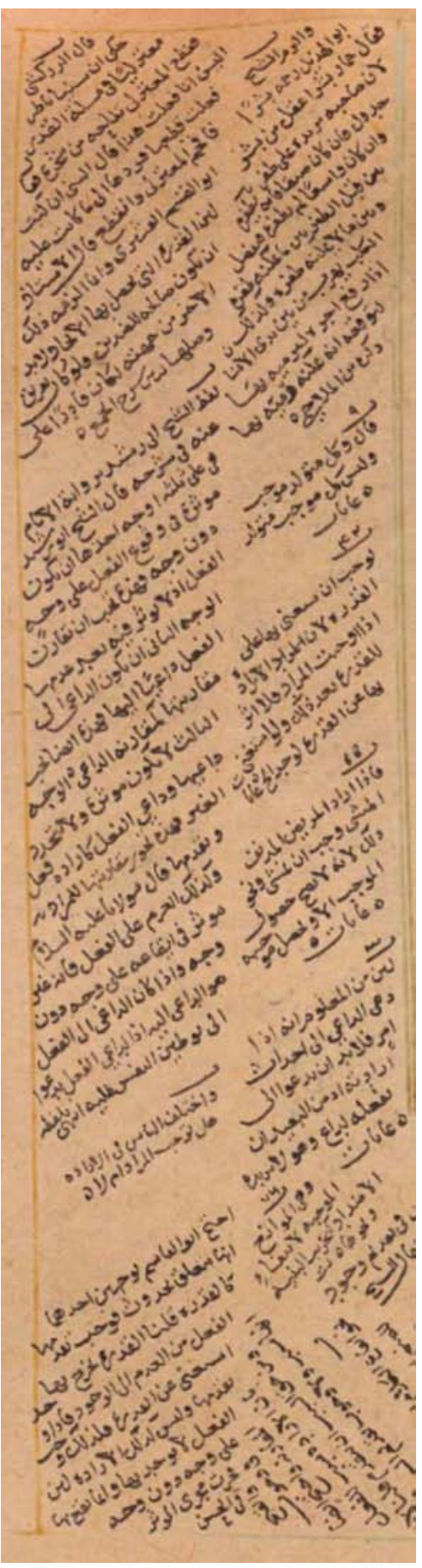

FIGURE 6.3

Ms Munich, Bavarian State Library, Cod. Arab. 1294, f. $37^{r}$ (hawā̌š top margin, rotated) 
[autograph]); commentary on Fahr al-Dīn al-Rāzī (d. 6o6/1210), K. Muhaṣ̂sșal afkār al-mutaqaddimin wa-l-mutäahhirīn min al-'ulamä’wa-l-ḥukamä wa-l-mutakallimin.

5. al-Raḍi [7a]: Raḍi al-Dīn Muhạmmad b. al-Ḥasan al-Astarābāḍī (d. 686/ 1287 or $688 / 1289$ ), unspecified.

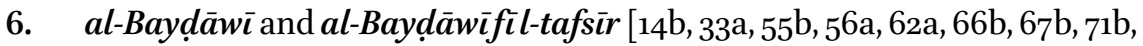
83b]: Nāṣir al-Dīn Abū l-Hูayr (/ Abū Saīd) 'Abd Allāh b. 'Umar al-Bayḍāwī (d. 716/1316; EncIr, vol. 4, pp. 15-17), Anwār al-tanzïl wa-asrār al-ta’wīl.

7. Mawāqif and al-Aḍd fì l-Muwāqafa(!) [6b, 10a (in later hand)]: 'Aḍud al-Dīn Abū l-Faḍl 'Abd al-Raḥmān b. Aḥmad b. 'Abd al-Gaffār al-Ī̄̄̄ì (d. 756/ 1355; $E I^{2}$, vol. 3, p. 1022), K. al-Mawāqiffí ilm al-kalām (GAL, vol. 2, p. $208 \mathrm{f}$;;

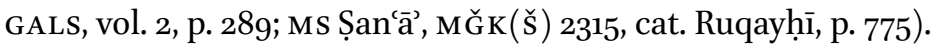

8. al-Subkīfì tarğamat al-Ašcarī [33a]: Tāğ al-Dīn Abū Nașr 'Abd al-Wahhāb b. Taqī l-Dīn al-Subkī (d. 771/1370;EI², vol. 9, p. 744), Țabaqāt al-Šäfíiyya al-kubrā.

9. Šarhal-'Aqā̉id (al-Nasafiyya) and Šarḥ al-Aqā̉id al-Sa'dī and (at times) Sa'd al-Din [20a, 3ob, 31b, 32a, 33a, 33b, 37b, 39a, 69b, 70a, 71a, 87a, 96b, 97a, 97b, 98a, 99a]: Sa'd al-Dīn Mas'ūd b. 'Umar al-Taftāzānī (d. 793/139o; $E I^{2}$, vol. 10, pp. 88-89), Šarh al-Aqā̇id al-Nasafiyya (GAL, vol. 2, p. 216 no. 11$) \cdot 106$

10. Sa'd al-Dīn and Sa'd al-Din min Šarh al-Kaššăf [23a, 23b, 39a(?), 63a, 69a, 81a, 85a]: Sa'd al-Dīn Mas'ūd b. 'Umar al-Taftāzānī (d. 793/139o; $E I^{2}$, vol. 10, pp. 88-89), Hāasizyat al-Kaššăf (GAL, vol. 2, p. 216 no. 12); glosses on al-Zamahšarīs Kaššăf. ${ }^{107}$

11. Sa'd al-Dīn [87a]: Sa'd al-Dīn Mas'ūd b. 'Umar al-Taftāzānī (d. 793/139o; $E I^{2}$, vol. 10, pp. 88-89), Šarh al-Maqāsid (GAL, vol. 2, p. 216 no. 10).

12. al-Zarkaš̄ fı̌ Šarḥ̆Ğam'al-Ğawāmi' and possibly also Šarḥ al-Ğam' [37a, 67b, 86b]: Abū 'Abd Allāh Badr al-Dīn Muḥammad b. 'Abd Allāh b. Bahādur al-Zarkašì (d. 794/1392; EI ${ }^{2}$, vol. 12, p. 842), Tašnîf al-masāmi' fi Ğam al-Ğawāmic (GAL, vol. 2, p. 89; GALS, vol. 2, p. 105); commentary on Tāğ alDīn al-Subkī’s (d. 771/1370) Ğam`al-Ğawāmi` (fì uṣūl al-figh) (GAL, vol. 2, p. 89; GALS, vol. 2, p. 105). ${ }^{108}$

13. al-Nağm al-wahhāğ fi šarḥ al-Minhāğ li-l-Damīrī [1b]: Abū l-Baqā' Muḥammad b. Mūsā al-Damīīi (d. 808/1405; $E I^{2}$, vol. 2, pp. 107-108), K. al-

106 'Sa'd al-Dīn' is used to refer to either Šarḥ al-'aqā'id al-nasafiyya or Šarh al-Maqāṣid or Hāšiyat al-Kaššăf.

107 See above n. 104.

108 Šarh al-Ğam` may also refer to Ğalāl al-Dīn al-Mahallī’s commentary on Ğam`al-Ğawāmic (see below). 
Nağm al-wahhāğ fi šarh al-Minhāğ (GALS, vol. 1, p. 681 no. 11), extracts from Taqī al-Dīn al-Subkī's (d. 756/1355) and Ğamāl al-Dīn al-Asnawì's (d. 772/1370) commentaries on Muhyī l-Dīn al-Nawawì's (d. 676/1277) Minhāğ al-tạlibìn wa-maslak al-rāgibiōn. ${ }^{109}$

14. Hayāt al-hayawān [20b, 71b]: Kamāl al-Dīn Muhạmmad b. Mūsā al-Damīrī (d. 808/1405; EI 2, vol. 2, pp. 107-108), K. Hayāt al-hayawān al-kubrā (GAL, vol. 2, p. 138; GALS, vol. 2, p. 171).

15. Šarḥ (al-)Mawāqif and al-Šarīffı Šarḥihi (ba'd al-'Aḍud) [6a, 10a, 56a, 59a]: al-Šarīf Zayn al-Dīn 'Alī b. Muhammad al-Ğurğānī (d. 816/1413; $E I^{2}$, vol. 2, p. 602 f.; van Ess, Die Träume der Schulweisheit [above n. 28], p. 42, 6o, 95), Šarḥ al-Mawāqif; commentary on 'Aḍud al-Dīn al-Īğî̀s (d. 756/ 1355) K. al-Mawāqiffı́ 'ilm al-kalām (see above).

16. Qāmūs [1b, 3b, 10b, 12a, 16b, 31a, 34a, 39a, 39b, 51a, 52a, 52b, 54b, $57 \mathrm{~b}$, 75a, 79b, 80a, 86b, 87b, 92a, 93b, 95b, 96b, 97b, 98a, 100a, 101a, 107b, 108a, 110a]: Abū l-Ṭāhir Muhammad b. Ya'qūb al-Fīrūzābādī (d. 817/1415; $E I^{2}$, vol. 2, pp. 926-927), al-Qāmūs al-muhît wa-l-qābūs al-wașịt al-ğāmic li-māa dahaba min luġat al-Arab šamāțtit (GAL, vol. 2, pp. 181-183; GALS, vol. 2, pp. 234-236); al-Fīrūzābādī spent the last two decades of his life in Yemen and in 797/1395 became chief Qāḍī of Yemen.

17. al-Buhāầ [54b]: This either refers to an unspecified work by 'Alä' al-Dīn Muḥammad b. Muḥammad al-Buhārī (d. 841/1438) or to Šams al-Dīn Muḥammad [al-Ḥāfizīi] al-Buhārī’s [known as Huwāğa-yi Pārsā] (d. 822/ 1419) Šarh al-Fiqh al-akbar.

18. al-Hițat wa-l-ātāar li-l-Maqrīzī or al-Hițat [8b, 37b]: Aḥmad b. 'Alī alMaqrīzī (d. 845/1442; EI ${ }^{2}$, vol. 6, pp. 193-194), K. al-Mawāiz wa-l-itibār fi dhikr al-hitaț wa-l-äthār (= al-Hițațal-Maqriziyya) (GAL, vol. 2, pp. 38-39; GALS, vol. 2, p. 36).

19. Šarh al-Ğam ' [37a]: One of the more popular commentaries on Tāğ al-Dīn al-Subkīs (d. 771/1370) Ğam'al-Ğawāmic (fìușūlal-figh) (GAL, vol. 2, p. 89; GALS, vol. 2, p. 105), most likely by Ğalāl al-Dīn al-Mahallī (d. 864/1460) or Badr al-Dīn al-Zarkašì (d. 794/1392).

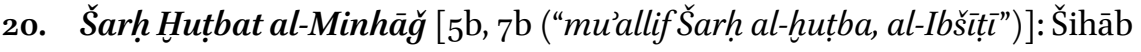
al-Dīn Aḥmad b. Ismā̄il al-Ibšițī (d. 883/1478; вт̣, pp. 67-69 no. 23; Mм, vol. 1, p. 63), commentary on the preamble of Muhyī l-Dīn Abū Zakariyyä' Yahyā b. Šaraf al-Nawawī (d. 676/1278), K. Minhāğ al-țālibin wa-maslak al-rägibìin (GAL ${ }^{2}$, p. 496 no. 29,I; GALS, vol. 1, p. 680).

109 Al-Damīrì's al-Nağm al-wahhāğ should not be confused with 'Alī b. Muhammad al-Bukurī's al-Kawkab al-wahhāğfı̌šrh al-Minhāğg (see above no. 25 under Zaydī compositions). 
21. Ğāmi' al-bayān [21b, 29b, 76b, 8ob]: Muhammad b. 'Abd al-Rahmān al-İğī (d. 905/1500), Ğāmi al-Bayān fì tafsìr al-Qur'ān (GAL, vol. 2, p. 203; GAL ${ }^{2}$, vol. 2, p. 261; GALS, vol. 2, p. 278 no. 10,1; al-Sahāwī, al-Paw' al-lāmi', vol. 8, p. 37).

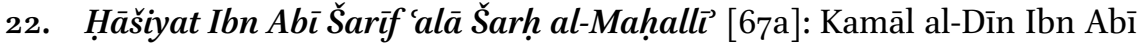
l-Šarīf al-Kawrānī al-Maqdisī (d. 906/1500), al-Durar al-lawāmic fì tahrīr Šarh Ğam' al-Ğawāmic (GAL, vol. 2, p. 89; GALS, vol. 2, p. 944 no. 147), i.e. glosses on Ğalāl al-Dīn al-Maḥalli’s's (d. 864/1460) al-Badr al-țālic fí haall Ğam' al-ğawāmic', a commentary on Tāğ al-Dīn al-Subkìs (d. 771/1370) Ğam'al-Ğawāmi' (fí uṣūlal-fiqh) (GAL, vol. 2, p. 89; GALS, vol. 2, p. 105).

23. al-Durral-națīrmuhtașar Nihāyat Ibn Ațīr li-l-Suwāțī [63a]: Ğalāl al-Dīn al-Suyūṭī (d. 911/1505; $E I^{2}$, vol. 9, pp. 913-916), al-Durr al-națìr fì talhịṣ Nihāyat Ibn al-Ațīr (GAL, vol. 1, p. 357), i.e. Suyūțīs Talhūṣ of Mağd al-Dīn al-Mubārak b. Muhammad Ibn al-Ațīr's (d. 606/1210) K. al-Nihāya fì garīb al-hadịt wa-l-atar (GAL, vol. 1, p. 357).

24. Fatḥ al-mubīn fi-šarḥ al-Arbaìn li-bn Hağar [110a]: Aḥmad b. Muḥammad Ibn Ḥağar al-Haytamī (d. 974/1567; $E I^{2}$, vol. 3, pp. 778-779; T.ZK, pp. 1370-1428 no. 845; see above n. 33), Fath al-mubin fi šarh al-Arbaìn (GAL, vol. 2, p. 387; GALS, vol. 1, p. 683).

25. Tafsïr Abı̀ Su'ūd or 'Abì Su'üd [24a (ad Q 13[al-Ra'd]:31)]: Abū l-Su'ūd Muhạmmad b. Muhỵi l-Dīn Muḥammad al-Imādī (d. 982/1574; EI², vol. 1, p. 152), Iršād al-'aql al-salìm ilā mazāyā l-Qur'ān al-karìm (GAL, vol. 1, p. 438 f.). The Tafsìr by al-Imādī ("Hoca Çelebi", "Ebussuud Efendi"), the 'Šayh al-Islām' of the Ottoman empire under Sulțān Sulaymān I. (952/ 1545-), was introduced to Yemen during the first Ottoman occupation.

26. al-Nibrās [83a]: 'Abd al-Wahhāb b. Ab̄̄ 'Abd Allāh al-Ganğ(aw)ī (MM, vol. 6, p. 224; вт̣, p. 166), K. al-Nibrās li-kašf al-iltibās al-wāqi' fì l-Asās li-'aqā̉id qawm sammū anfusahum bi-l-Akyās (GAL, vol. 2, p. 330; GALS, vol. 2, p. 457 no. 7). ${ }^{110}$ The Nibrās by the Damascene Ašcarite-Šāfíite al-

110 GAL, vol. 2, p. 330, GAL ${ }^{2}$, vol. 2, p. 433, GALS, vol. 2, p. 457 no. 7; MM, vol. 6, p. 224. See also the editor's introduction in Aḥmad b. Muḥammad b. Șalāḥ al-Šarafì's (d. 1055/1646) Šifä’ șudūr al-nās bi-šarh ma'ānī l-Asās (= Šarh al-Asās al-kabìr), Șanāà, Dār al-Ḥikma al-Yamāniyya, 1991, vol. 1, p. 21. Āg̀ā Buzurg al-Ṭihrānī, al-Dֵarīa ilā tașānīf al-Šǐca, Beirut, Dār al-Aḍwā', 1983, who-like al-Šawkānī—attributes the Nibrās to Šihāb al-Dīn Ibrāhīm b. Ḥasan al-Kūrānī al-Kurdī (d. 1101/169o; BṬ, pp. 42-43 no. 6), refers to an additional copy of the Nibrās in Nağaf. An identification 'al-Nibräs' with K. al-Nibrās (Šarh šarh al-'aqā’id), a commentary by the Ḥanafì Muhammad 'Abd al-'Azīz b. Muḥammad al-Farhārī (d. ca. 1241/1825-1826) on al-Taftāzānī's Šarh al-'aqā’id al-Nasafiyya, must be excluded for chronological reasons. 


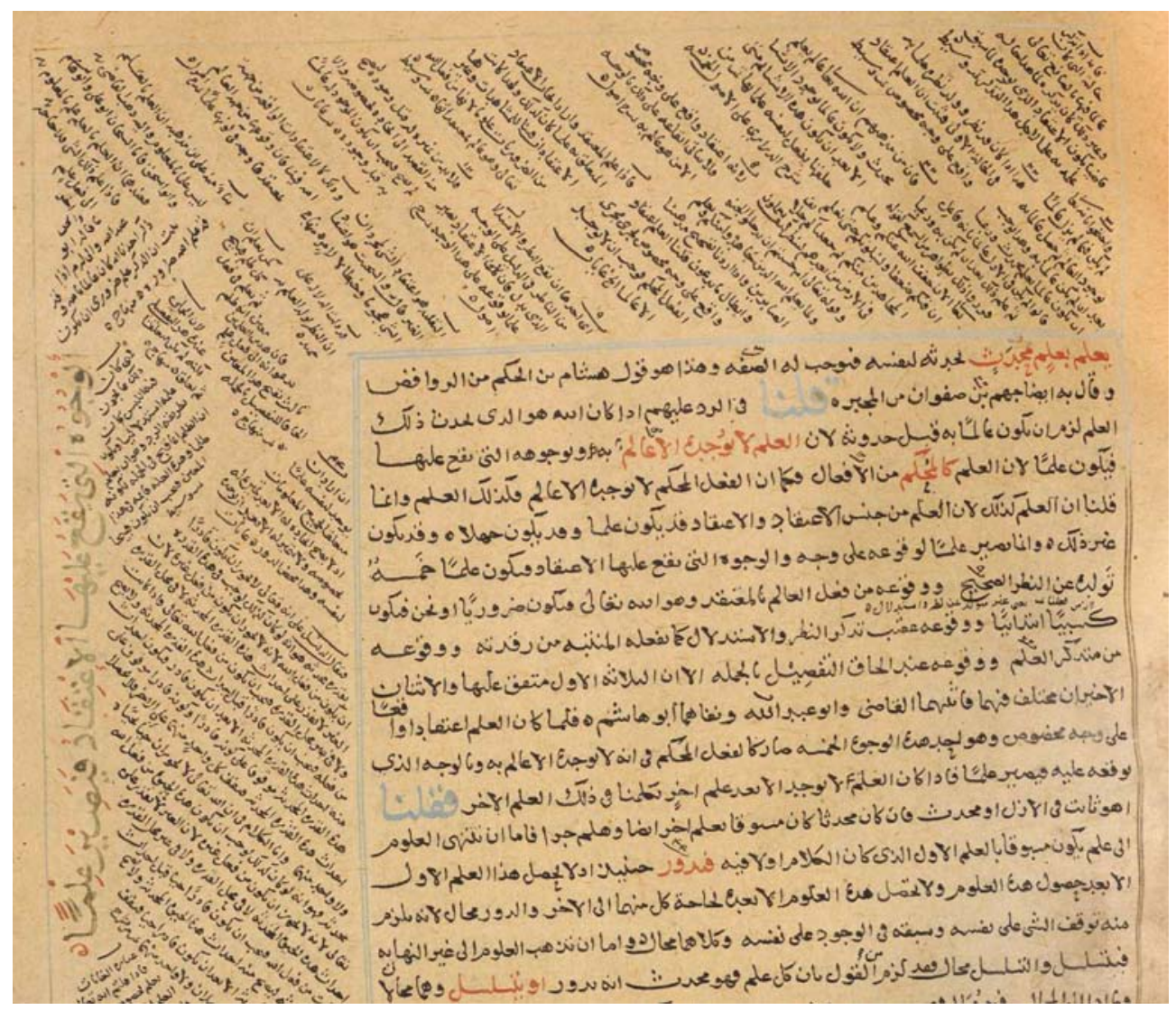

FIGURE 6.4 MS Munich, Bavarian State Library, Cod. Arab. 1294, f. $8^{r}$ (upper half)

Ganğ(aw)ī, completed in 1062/1652, was written in refutation of $K$. al-Asās li-taṣḥ̄h 'aqāiid al-akyās by Imām al-Mansụ̂r bi-llāh al-Qāsim b. Muḥam$\operatorname{mad}$ (d. 1029/1620; see above no. 30), the founder of the Qāsimī dynasty, and thus directed against the centre of power of the early Qāsimī state which after the end of the first Ottoman occupation in 1636 encompassed from 1670 onwards both Upper and Lower Yemen with its many Šāfi $\overline{1}-$ Aš́arī subjects. The Nibrās is an important piece of evidence for the early reception of K. al-Asās outside of Yemen, in Iraq and Syria. The Nibrās was in turn refuted by Isḥāq b. Muḥammad al-Abdī (d. 1115/1703; BṬ, pp. 166167 no. 83) in the bulky K. al-Ihtirās 'an nār al-Nibrās al-țā' in fì qawā'id al-Asās. ${ }^{111}$ Another refutation of the Nibrās, entitled al-Qustāas fi l-radd

111 Interestingly, al-Šawkānī, BṬ, pp. 166-167 (167, ll. 2-3) no. 83, notes that al-'Abdī resorted to 
'alā Șâhib al-Nibrās (unfinished), was written by Zayd b. Muḥammad b. al-Ḥasan b. al-Manșūr bi-llāh al-Qāsim (d. 1123/1711) who-as mentioned above-sponsored and supervised the copy of MS Munich Cod. arab. $1294 .{ }^{112}$

Some sources erroneously give Šihāb al-Dīn Ibrāhīm b. Ḥasan al-Kūrānī al-Šahrazūrī al-Kurdī (d.1101/169o; GAL II:385-866; GAL II:505-507; GALS II:520 f.) as author of the Nibrās. This confusion may be due to the fact that al-Kurdī is the author of $K$. Nïbrās al-inās bi-ağwibat su'ālāt ahl Fās and of a commentary (see http://pudl.princeton.edu/objects/4x51hj43c; I am grateful to Harith bin Ramli for this reference) on al-Aqida alșahịha wa-l-dīn al-nașịha (ed. Șanāà: Dār al-Turāt al-Yamanī, 1995) by Imām al-Mutawakkil Ismāeil b. al-Qāsim (d.1087/1676) whose sìra is found in Muțahhar b. Muḥammad al-Ğarmūzì's (d.1077/1666) Tuhfat al-asmä $\bar{a}^{2}$ wa-l-abșār bi-mā fìl-sīra al-Mutawakkiliyya min ġarāib al-aḩbār (ed. 'Ammān: IZbACF 2002).

some of the main sources of the Nibrās such as al-İ̄̄̄'s K. al-Mawāqif, al-Taftāzānī's K. alMaquạsid and al-Samarqandī's Šarh al-Tağrīd to prove the incoherence of the author's argu-

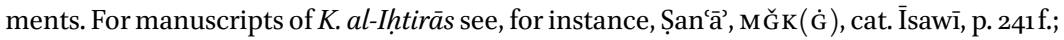
http://libback.uqu.edu.sa/hipres/SCRIPT/ind11968.pdf; http://libback.uqu.edu.sa/hipres/ SCRIPT/ind13636-2.pdf; http://pudl.princeton.edu/objects/v405sb679 [consulted 30/11/ 2013]. I intend to dedicate a more detailed study to K. al-Nibrās and its Zaydī refutations in the future.

112 BṬ, pp. 293-296 (295) no. 176; MFY, p. 155. 